\title{
FORAMINIFERAL ASSEMBLAGES FROM THE BAJOCIAN GLOBAL STRATOTYPE SECTION AND POINT (GSSP) AT CAPE MONDEGO (PORTUGAL)
}

\author{
M. Luisa CAnales ${ }^{1,3}$ and M. Helena Henriques ${ }^{2}$
}

\section{ABSTRACT}

A detailed study of the benthic foraminiferal assemblages at the Bajocian Global Stratotype Section and Point (GSSPMurtinheira section, Lusitanian Basin, western Portugal) presented herein increases the correlation potential of this relevant global geological time reference. The recorded assemblages are relatively abundant and diverse, and are composed of wellpreserved taxa typical of the Boreal Realm. The most abundant suborders are Lagenina and Spirillinina. Representatives of the Suborder Textulariina are also abundant in some assemblages, while those of the suborders Robertinina and Rotaliina are scarce. Lenticulina specimens are the most abundant in all assemblages, but at the specific level, there are differences between Aalenian and Bajocian assemblages, with Lenticulina muensteri being most abundant in the former and Spirillina orbicula in the latter.

Two biozones, based on calcareous foraminifers, have been established and calibrated to the standard ammonite zonation: 1) the Lenticulina quenstedti Zone, ranging from the upper part of the Gigantea Subzone, Bradfordensis Biozone, upper Aalenian, to the lower part of the Discites Biozone, lower Bajocian, and 2) the Ramulina spandeli Zone, beginning at the top of the preceeding zone and having an undefined upper boundary. In addition, 11 bioevents are defined on first occurrences, last occurrences, changes in abundances of some taxa, or changes in assemblage diversity. After a severe impoverishment at the AalenianBajocian transition, an important foraminiferal turnover takes place in the early Bajocian, where some Lower Jurassic and Aalenian forms are replaced by typical Middle Jurassic taxa.

\section{INTRODUCTION}

The Murtinheira section, located $200 \mathrm{~km}$ north of Lisbon and $40 \mathrm{~km}$ west of Coimbra (Fig. 1) at Cape Mondego in the Lusitanian Basin of western Portugal, became an international reference outcrop in 1996 due to its establishment as the Bajocian Global Stratotype Section and Point (GSSP) by the International Union of Geological Sciences (IUGS). The ratification of the Murtinheira section as GSSP was based on ammonite and calcareous nannofossil assemblages and on magnetostratigraphy (Henriques and others, 1994; Pavia and Enay, 1997).

Several studies dealing with other fossil groups have been undertaken in the last few years to complete the paleontological knowledge of this reference section, including brachiopods (Andrade, 2004, 2006), calcareous nannofossils (Perilli and others, 2002a, 2002b; Henriques and others, 2010; López-Otálvaro and others, 2012), and foraminifers (Canales

\footnotetext{
${ }^{1}$ Departamento y UEI de Paleontología, Facultad de Ciencias Geológicas, Universidad Complutense de Madrid, e Instituto de Geología Económica (CSIC-UCM), c/José Antonio Novais, 2, 28040 Madrid, Spain

${ }^{2}$ Departamento de Ciências da Terra e Centro de Geociências, Faculdade de Ciências e Tecnologia, Universidade de Coimbra, 3000272 Coimbra, Portugal

${ }_{3}^{3}$ Correspondence author. E-mail: mcanales@geo.ucm.es
}

and others, 2000; Canales and Henriques, 2007, 2008; Henriques and others, 2008, 2010; Magno and others, 2008).

Detailed studies on lower Bajocian foraminifers from this GSSP have not been undertaken until now. The purposes of this work, therefore, are to determine the taxonomic composition and biostratigraphy of the foraminiferal assemblages across the Bajocian GSSP from the middle Aalenian, Bradfordensis Biozone, Gigantea Subzone, to the lower Bajocian, Laeviuscula Biozone, Ovalis Subzone. These aspects will broaden our understanding about this important group of microfossils in this Jurassic reference section, and will enlarge the paleontological knowledge of the Bajocian GSSP, thus increasing its correlation potential.

\section{THE UPPER AALENIAN-LOWER BAJOCIAN BOUNDARY AND THE BAJOCIAN GSSP}

The Murtinheira section comprises a thick series of marine, upper Toarcian-Callovian rocks of the Cabo Mondego Formation (Azerêdo and others, 2003) and OxfordianTithonian littoral beds, outcropping continuously along the coast. The section represents a geosite of international relevance due to its stratigraphic value (Henriques and others, 1998; Henriques, 2004; Brilha and others, 2005; Henriques and Ramalho, 2005; Pena dos Reis and Henriques, 2009), and these outcrops have been recently protected as a natural monument (Henriques, 2008; ICNB, 2009). It includes, besides the Bathonian Auxiliary Stratotype Section and Point (ASSP; Fernández-López and others, 2006, 2007, 2009), the Bajocian GSSP, which was the first stage boundary established for the Jurassic System by the IUGS (Pavia and Enay, 1997). The "golden spike" has been situated within a hemipelagic lithofacies composed of alternating gray limy mudstone and marlstone beds (Fig. 2) with gradational boundaries (Watkinson, 1989), providing rich and diversified ammonite assemblages (Henriques 1992; Henriques and others, 1996).

The upper Aalenian sediments contain two ammonite subzones of the Concavum Biozone (Henriques, 1992, 1995). The Concavum Subzone is defined by the first occurrence of the index species Graphoceras concavum (Sowerby) together with other Graphoceras ("Ludwigella") spp.; the first representatives of Haplopleuroceras and Riccardiceras longalvum (Vacek) also occur in this subzone. The Limitatum Subzone is defined by the first occurrence of the index species $G$. limitatum Buckman, associated with different species of Euaptetoceras, Eudmetoceras, Haplopleuroceras, Docidoceras, Euhoploceras, and Braunsina among others. Its upper boundary is recognized by the first occurrence of different species of HyperliocerasToxolioceras (Mouterde and others, 1972; FernándezLópez and others, 1988a, 1988b; Henriques and others, 1988; Rocha and others, 1990; Henriques and others, 1996).

The Discites Biozone, whose lower boundary coincides with the Bajocian GSSP (at bed AB11 or M-335 in this 


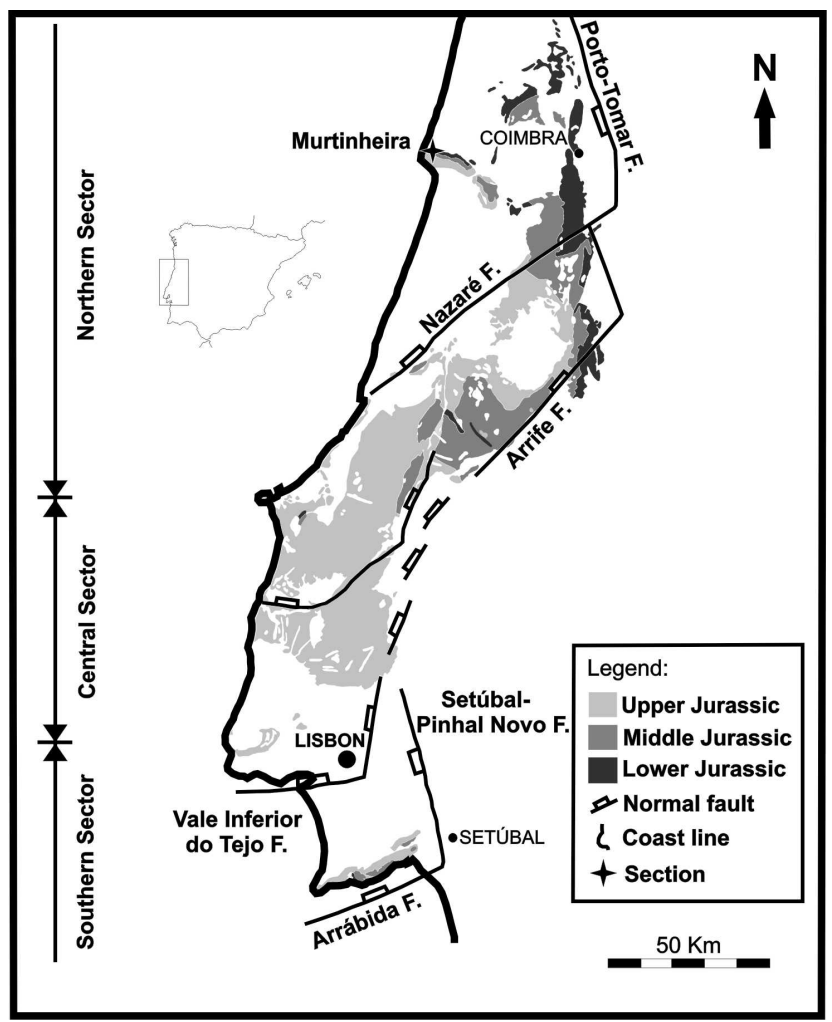

FIGURE 1. Geologic map of the Lusitanian Basin (west side of the Iberian Peninsula), showing the Jurassic outcrops and location of the Murtinheira section (modified after Figueiredo, 2009).

work, Fig. 2), is mainly characterized by species of the genus Hyperlioceras, and its lower boundary is defined by the first occurrence of an ammonite assemblage with Hyperlioceras mundum (Buckman) and related species (Pavia and Enay, 1997). Other ammonite taxa, like Zurcheria and Fontannesia, and different species of Sonninia and Euhoploceras among others, are also represented (Fernández-López and others, 1988a, 1988b; Rocha and others, 1990; Henriques, 1992, 1995; Henriques and Mouterde, 2000; Henriques and others, 1988, 1996).

The Bajocian GSSP coincides with an inversion from reversed to normal polarity, which can be correlated with the Jurassic magnetic polarity time scale (Pavia and Enay, 1997). The nannofossil record points to a gradual turnover across the Aalenian-Bajocian boundary with slight changes in nannofossil dominance rather than abrupt appearances or disappearances of taxa (Rocha and others, 1990; Henriques and others, 1994).

The first representatives of Fissilobiceras and Witchelia characterize the lower boundary of the overlying Laeviuscula Biozone and Ovalis Subzone, but Bradfordiinae and Otoitiidae are locally very frequent in this subzone (Fernández-López and others, 1988a).

\section{MATERIAL AND METHODS}

Sixteen samples were collected, processed, and analyzed to study the middle Aalenian (Bradfordensis Biozone, Gigantea Subzone)-lower Bajocian (Laeviuscula Biozone, Ovalis Subzone) foraminifers from the Murtinheira section.
Specific marly or marly limestone levels were sampled, based on biostratigraphic data provided by the ammonoid record (Henriques, 1992), and the number of samples collected from each ammonite subzone depended upon the thickness of that subzone. Samples were identified as M (Murtinheira section) followed by the number of the stratigraphic level in the section (Fig. 2).

Approximately $300 \mathrm{~g} / \mathrm{sample}$ were treated with an industrial surfactant liquid (Amine-O), combined with acetic acid and water (Ruget and others, 1989), and then washed in a column of mesh sieves $(1 \mathrm{~mm}, 0.500 \mathrm{~mm}$, $0.250 \mathrm{~mm}, 0.125 \mathrm{~mm}$, and $0.060 \mathrm{~mm}$ ). A Wild M-8 binocular microscope was used to pick foraminifers from the residues. Suprageneric and generic identifications followed the classification of Loeblich and Tappan (1987), and the Ellis and Messina (1940-1990) Catalogue of Foraminifera was systematically consulted. The figured specimens were photographed with a JEOL-JSM 6400 electron microscope located in the Centro Nacional de Microscopía Electrónica at the Universidad Complutense de Madrid (Spain).

All sample residues and specimens are stored at the Laboratório de Geologia Sedimentar e Registo Fóssil, located in the Departamento de Ciências da Terra, Faculdade de Ciências e Tecnologia, Universidade de Coimbra (Portugal).

\section{RESULTS}

\section{INTRODUCTION}

A total of 3949 foraminifers were obtained from the studied samples, most of them showing good preservation. However, 148 specimens, or $3.75 \%$ of the collection, cannot be assigned to any known species. Taphonomic processes affecting the foramininifers include test breakage, incipient or partial dissolution of the wall, recrystallization, deformation, and borings (Herrero and Canales, 2002), but, in most cases, none of them hindered species identification.

Most assemblages are abundant and diverse, comprising a relatively high number of specimens and taxa. Their composition varies throughout the measured section, showing a progressive disappearance of typical Lower Jurassic species that extend into the Aalenian and the first appearance of species described from the Middle Jurassic in other areas of the Boreal Realm. The first (FO) or last (LO) occurrence of certain species, as well as changes in relative abundances of some taxa, allow the establishment of useful local biostratigraphic events, which are described later in the text.

\section{Systematic Paleontology}

Fifty-four species have been identified from the Bajocian GSSP, corresponding to five suborders, eight superfamilies, 12 families, 12 subfamilies, and 24 genera. Species descriptions include references to original publications listed in Ellis and Messina (1940-1990), brief morphologic descriptions (some with remarks), stratigraphic distribution within the Murtinheira section, and the number of specimens recovered. Most species are illustrated in Figures $3-5$, and their stratigraphic position is located in Figure 2. 


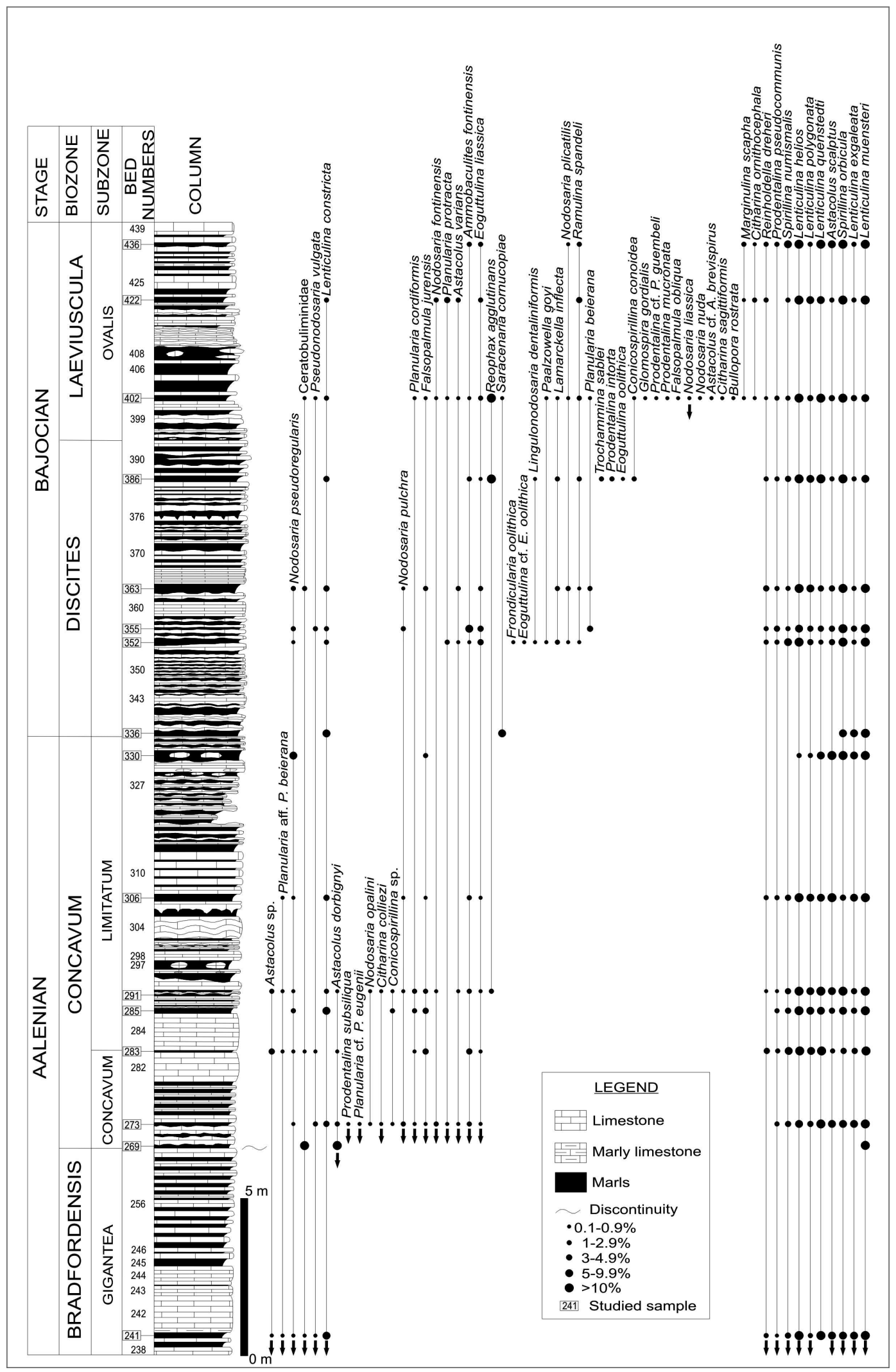

FIGURE 2. Lithologic succession, ammonite biozones, stratigraphic position of studied samples, and foraminiferal ranges with relative abundances (black dots) in each sample. 
Order FORAMINIFERIDA Eichwald, 1830

Suborder TEXTULARIINA Delage and Hérouard, 1896

Superfamily AMMODISCACEA Reuss, 1862

Family AMMODISCIDAE Reuss, 1862

Subfamily AMMOVERTELLININAE Saidova, 1981

Genus Glomospira Rzehak, 1885

Type species: Trochammina squamata Jones and Parker var. gordialis Jones and Parker, 1860

Glomospira gordialis (Jones and Parker, 1860)

Fig. 3.1

Trochammina squamata var. gordialis Jones and Parker, 1860, p. 304.

Description. Very finely agglutinated test with a smooth external appearance. Proloculus not visible, followed by an undivided, irregularly coiled, tubular chamber. Aperture is located at the end of the tube. Surface is unornamented.

Occurrence and age. Lower Bajocian, Laeviuscula Biozone, Ovalis Subzone (sample M-402).

Material. Two specimens.

Superfamily HORMOSINACEA Haeckel, 1894

Family HORMOSINIDAE Haeckel, 1894

Subfamily REOPHACINAE Cushman, 1910

Genus Reophax de Montfort, 1808

Type species: Reophax scorpiurus de Montfort, 1808

Reophax agglutinans (Terquem, 1870a)

Fig. 3.2

Nodosaria agglutinans Terquem, 1870a, p. 354, pl. 29, figs. 8a, b.

Description. Test is agglutinated and consists of a straight to slightly curved series of uniserial, subrounded chambers, slowly increasing in size, that are separated by horizontal and depressed sutures, giving rise to nearly parallel and sublobular lateral margins. Aperture is rounded, located in the central part of the last chamber.

Occurrence and age. Upper Aalenian, Concavum Biozone, Limitatum Subzone-lower Bajocian, Laeviuscula Biozone, Ovalis Subzone (samples M-291-402).

Material. 207 specimens.

Superfamily LITUOLACEA de Blainville, 1827

Family LITUOLIDAE de Blainville, 1827

Genus Ammobaculites Cushman, 1910

Type species: Spirolina agglutinans d'Orbigny, 1846

Ammobaculites fontinensis (Terquem, 1870a)

Fig. 3.3

Haplophragmium fontinense Terquem, 1870a, p. 235, pl. 24, figs. 29, 30.

Description. Agglutinated test displaying a planispiralevolute initial portion with up to seven chambers in the last whorl, followed by an uncoiled series of 2-4 chambers, all of them regularly increasing in size as added. Sutures are flat to slightly arched and depressed, giving rise to lobulate margins. Aperture is rounded, located at the end of the last chamber.

Occurrence and age. Upper Aalenian, Concavum Biozone, Concavum Subzone-lower Bajocian, Laeviuscula Biozone, Ovalis Subzone (samples M-273-436).

Material. 37 specimens.

Superfamily TROCHAMMINACEA Schwager, 1877 Family TROCHAMMINIDAE Schwager, 1877

Subfamily TROCHAMMINIINAE Schwager, 1877

Genus Trochammina Parker and Jones, 1859

Type species: Nautilus inflatus Montagu, 1808

Trochammina sablei Tappan, 1955

Fig. 3.4
Trochammina sablei Tappan, 1955, p. 50, 51, pl. 14, figs. 6-9.

Description. Test is agglutinated, circular in outline, with the chambers showing a low trochospiral coil, and increasing gradually in size as added. Spiral side is convex and evolute; umbilical side is flat-slightly concave and involute, showing up to five chambers. Sutures are radial, straight, and slightly depressed, giving rise to a lobulate margin. Aperture is not visible in the recovered specimens.

Occurrence and age. Lower Bajocian, Discites Biozone (sample M-386).

Material. Four specimens.

Suborder SPIRILLININA Hohenegger and Piller, 1975

Family SPIRILLINIDAE Reuss and Fritsch, 1861 Genus Conicospirillina Cushman, 1927

Type species: Spirillina trochoides Berthelin, 1879

Conicospirillina conoidea (Paalzow, 1917)

Fig. 3.5

Spirillina conoidea Paalzow, 1917, p. 217, pl. 41, figs. 8a, b.

Description. Calcitic test, conical in shape, triangular in section, and circular in outline. Spherical proloculus is followed by a single, undivided tubular chamber coiled in a low trochospire, gradually increasing in diameter. Suture is slightly elevated. Spiral side is evolute and convex; umbilical side is slightly convex and involute. Aperture is not visible in the recovered specimens.

Occurrence and age. Lower Bajocian, Discites BiozoneLaeviuscula Biozone, Ovalis Subzone (samples M-386402).

Material. Four specimens.

Conicospirillina $\mathrm{sp}$.

Fig. 3.6

Conicospirillina sp. 1 of Canales, 2001, p. 275, pl. 4, figs. 1, 2.

Description. Calcitic test, conical in shape, almost hemispherical in section and circular in outline. Small spherical proloculus followed by an undivided, trochospirally coiled, tubular chamber of almost constant diameter. Suture is slightly elevated. Spiral side is evolute and convex; umbilical side is slightly concave and involute. Aperture is not visible in the recovered specimens.

Remarks. It differs from C. conoidea in the more convex shape and greater height of the test, the almost nonexistent increase in the diameter of the tube, and the concave umbilical side that is convex in $C$. conoidea.

Occurrence and age. Upper Aalenian, Concavum Biozone, Concavum Subzone-Limitatum Subzone (samples M-273-291).

Material. Four specimens.

Genus Spirillina Ehrenberg, 1843

Type species: Spirillina vivipara Ehrenberg, 1843

Spirillina numismalis Terquem and Berthelin, 1875

Fig. 3.7

Spirillina numismalis Terquem and Berthelin, 1875, p. 17, pl. 1, fig. 13 .

Description. Calcitic test, discoidal, with a small spherical proloculus followed by an evolute, planispirally coiled, undivided tubular chamber, displaying 4-8 whorls. Tube diameter is almost constant. Suture is slightly depressed. 


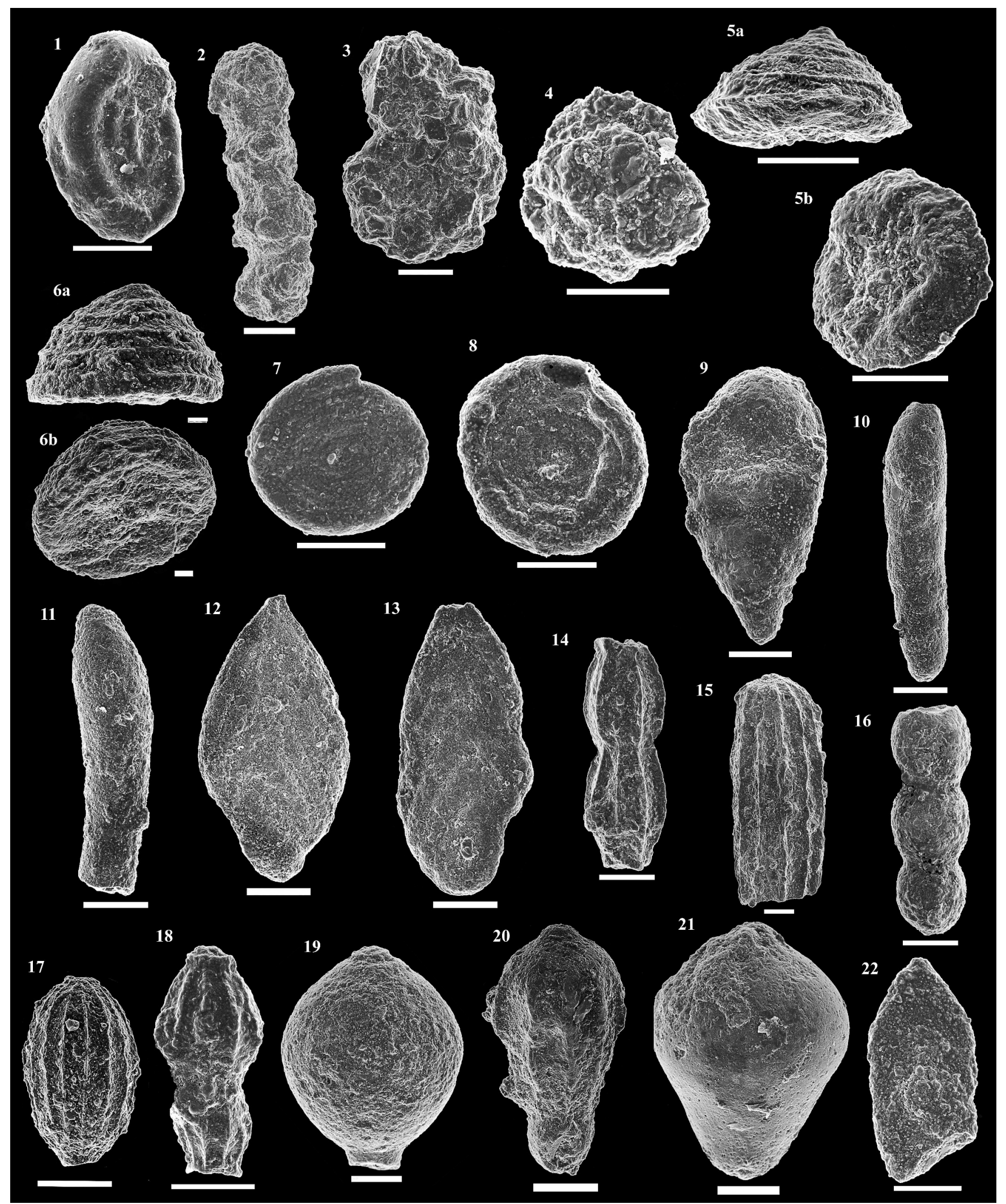

FIGURE 3. Selected Bajocian GSSP foraminifers belonging to the suborders Textulariina, Spirillinina, and Lagenina in the Murtinheira section Scale bars $=100 \mu \mathrm{m}$ unless indicated otherwise. 1 Glomospira gordialis, M-402-1-177, lower Bajocian, Laeviuscula Biozone, Ovalis Subzone. 2 Reophax agglutinans, M-402-2-178, lower Bajocian, Laeviuscula Biozone, Ovalis Subzone. 3 Ammobaculites fontinensis, M-386-1-128, lower Bajocian, Discites Biozone. 4 Trochammina sablei, M-386-2-129, lower Bajocian, Discites Biozone. 5 Conicospirillina conoidea: a, lateral view, M-386-4-181; b, apertural side, M-386-4-180; lower Bajocian, Discites Biozone. 6 Conicospirillina sp. (scale bar = $10 \mu \mathrm{m}$ ): a, lateral view, M-273-1346; b, apertural side, M-273-1346; upper Aalenian, Concavum Biozone, Concavum Subzone. 7 Spirillina numismalis, M-402-5-87, lower Bajocian, 
The simple aperture is located at the end of the tube. Test surface is smooth.

Occurrence and age. Middle Aalenian, Bradfordensis Biozone, Gigantea Subzone-lower Bajocian, Laeviuscula Biozone, Ovalis Subzone (samples M-241-436).

Material. 144 specimens.

Spirillina orbicula Terquem and Berthelin, 1875 Fig. 3.8

Spirillina orbicula Terquem and Berthelin, 1875, p. 17, pl. 1, figs. 12a-c.

Description. Calcitic test, discoidal, with a small spherical proloculus followed by an evolute, planispirally coiled, undivided tubular chamber of 4-7 whorls. The tube increases its diameter regularly with growth and partially overlaps the preceding whorl. Suture is slightly depressed. The simple aperture is located at the end of the tube. Test surface is smooth.

Occurrence and age. Middle Aalenian, Bradfordensis Biozone, Gigantea Subzone-lower Bajocian, Laeviuscula Biozone, Ovalis Subzone (samples M-241-436).

Material. 563 specimens.

Suborder LAGENINA Delage and Hérouard, 1896 Superfamily ROBULOIDACEA Reiss, 1963

Family ICHTHYOLARIIDAE Loeblich and Tappan, 1986 Genus Lingulonodosaria Silvestri, 1903

Type species: Lingulina nodosaria Reuss, 1863

Lingulonodosaria dentaliniformis (Terquem, 1870a)

Fig. 3.9

Lingulina dentaliniformis Terquem, 1870a, p. 237, 238, pl. 25, figs. 1-3.

Description. Calcitic test, elongated, rectilinear, uniserial, slightly compressed, and ovate in section. Proloculus is spherical, followed by chambers initially wider than high, with the last one higher than wide, increasing in size regularly with growth. Sutures are arched, flush, or slightly depressed; consequently, lateral margins of the test are divergent and sometimes lobulate. Aperture is ovate and located in the central part of the last chamber. Surface is smooth.

Occurrence and age. Lower Bajocian, Discites Biozone (samples M-352-386).

Material. Three specimens.

Genus Prodentalina Norling, 1968

Type species: Dentalina terquemi d’Orbigny, 1850

Prodentalina cf. P. guembeli (Schwager, 1865)

Dentalina gümbeli Schwager, 1865, p. 101, pl. 2, fig. 20.

Description. Calcitic test, elongated, uniserial, initially arched, later straight, and circular in section. Proloculus is small and ovate, followed by numerous chambers broader than high, except fot the last one that is higher than broad and inflated. Sutures are slightly oblique and flush to depressed. Aperture is not preserved in the recovered specimens. Test surface is smooth.

Remarks. The scarce specimens found in this study show morphological features very similar to those of $P$. guembel $i$ (Schwager). However, they are recrystallized, broken, and distorted, which hinders unequivocal identification as it is not possible to observe the total number of chambers, the features of the sutures, or the aperture. No specimens are illustrated in this paper.

Occurrence and age. Lower Bajocian, Laeviuscula Biozone, Ovalis Subzone (sample M-402).

Material. Two specimens.

$$
\text { Prodentalina intorta (Terquem, 1870a) }
$$

Dentalina intorta Terquem, 1870a, p. 364, pl. 27, figs. 26-34.

Description. Calcitic test, elongated, uniserial, and slightly arched with a circular section. Proloculus is ovate, followed by $5-6$ chambers, initially wider than high, with the last one as wide as high, increasing gradually its size as added. Sutures are straight and oblique, sligthly depressed; consequently, lateral margins are slightly divergent and lobulate. Aperture is terminal, radiate, and located excentrically in the last chamber. Surface is smooth.

Remarks. No specimens are illustrated in this paper.

Occurrence and age. Lower Bajocian, Discites Biozone (sample M-386).

Material. Three specimens.

\section{Prodentalina mucronata (Neugeboren, 1856)}

Fig. 3.10

Dentalina mucronata Neugeboren, 1856, p. 86, pl. 3, figs. 8-11.

Description. Calcitic test, elongated, uniserial, and almost straight with a circular section. Proloculus is ovate, followed by four chambers as wide as high, except the last one that is $2 \times$ higher than wide. Sutures are oblique, flush, or very slightly depressed. Lateral margins of the test are subparallel and almost without lobulation. Apertural area is broken in the only specimen found. Test surface is smooth.

Occurrence and age. Lower Bajocian, Laeviuscula Biozone, Ovalis Subzone (sample M-402).

$$
\text { Prodentalina pseudocommunis (Franke, 1936) }
$$

Fig. 3.11

Dentalina pseudocommunis Franke, 1936, p. 30, pl. 2, figs. 20a, b.

$\leftarrow$

Laeviuscula Biozone, Ovalis Subzone. 8 Spirillina orbicula, M-402-6-88, lower Bajocian, Laeviuscula Biozone, Ovalis Subzone. 9 Lingulonodosaria dentaliniformis, M-352-9-136, lower Bajocian, Discites Biozone. 10 Prodentalina mucronata, M-402-7-184, lower Bajocian, Laeviuscula Biozone, Ovalis Subzone. 11 Prodentalina pseudocommunis, M-436-8-185, lower Bajocian, Laeviuscula Biozone, Ovalis Subzone. 12 Falsopalmula jurensis, M402-9-186, lower Bajocian, Laeviuscula Biozone, Ovalis Subzone. 13 Falsopalmula obliqua, M-402-10-187, lower Bajocian, Laeviuscula Biozone, Ovalis Subzone. 14 Nodosaria fontinensis, M-402-17-99, lower Bajocian, Laeviuscula Biozone, Ovalis Subzone. 15 Nodosaria liassica, M-402-16-143, lower Bajocian, Laeviuscula Biozone, Ovalis Subzone. 16 Nodosaria nuda, M-402-32-210, lower Bajocian, Laeviuscula Biozone, Ovalis Subzone. 17 Nodosaria opalini, M-291-13-51, upper Aalenian, Concavum Biozone, Limitatum Subzone, 18 Nodosaria plicatilis, M-402-12-189, lower Bajocian, Laeviuscula Biozone, Ovalis Subzone. 19 Nodosaria pseudoregularis, M-291-1-294, upper Aalenian, Concavum Biozone, Limitatum Subzone. 20 Nodosaria pulchra, M-291-1317, upper Aalenian, Concavum Biozone, Limitatum Subzone. 21 Pseudonodosaria vulgata, M-355-4-297, lower Bajocian, Discites Biozone. 22 Frondicularia oolithica, M-352-13-190, lower Bajocian, Discites Biozone. 


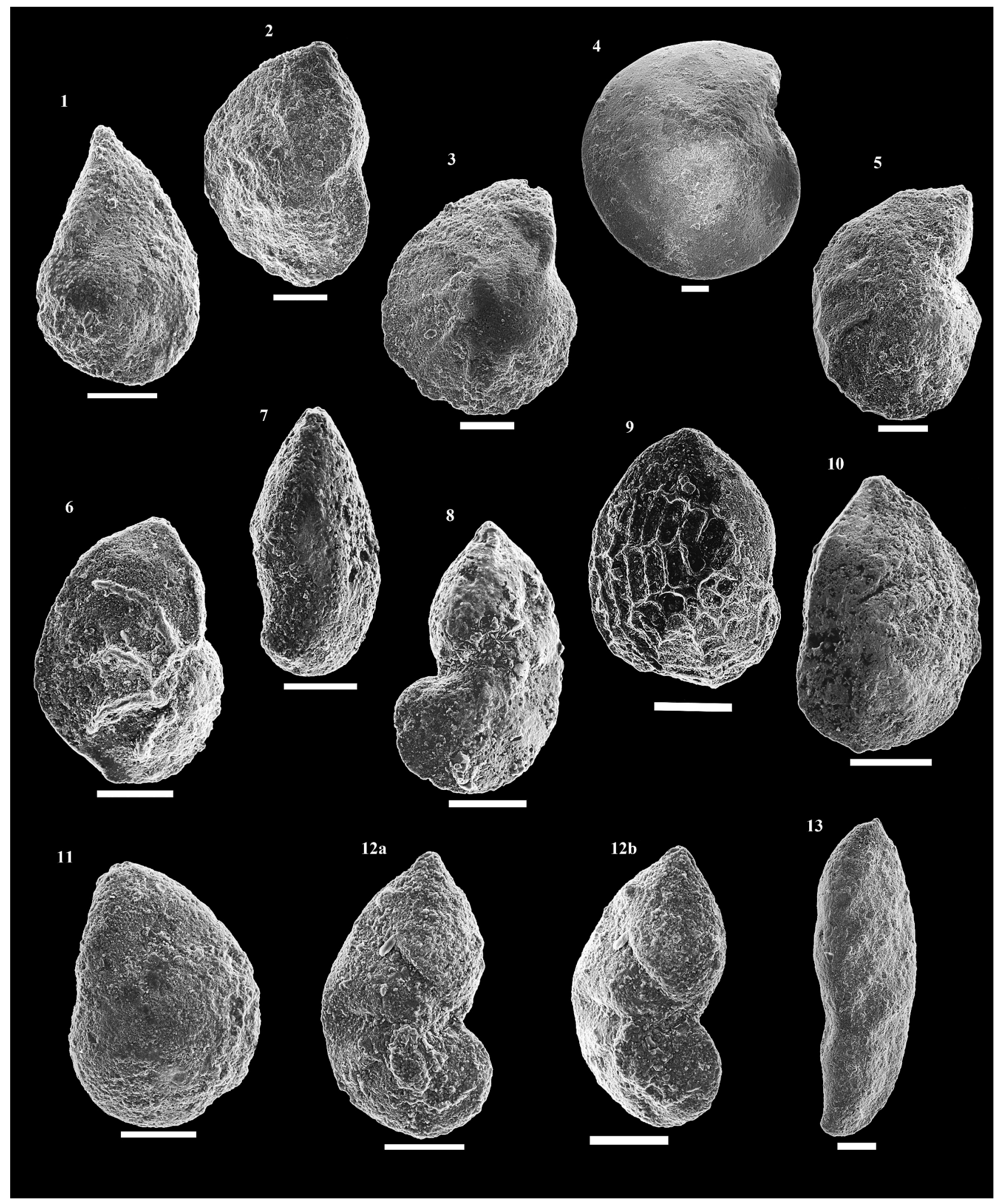

Figure 4. Selected Bajocian GSSP foraminifers belonging to the Suborder Lagenina in the Murtinheira section. Scale bars $=100 \mu \mathrm{m}$. 1 Lenticulina constricta, M-402-21-103, lower Bajocian, Laeviuscula Biozone, Ovalis Subzone. 2 Lenticulina exgaleata, M-352-14-191, lower Bajocian, Discites Biozone. 3 Lenticulina helios, M-291-6-301, upper Aalenian, Concavum Biozone, Limitatum Subzone. 4 Lenticulina muensteri, M-422-25-109, lower Bajocian, Laeviuscula Biozone, Ovalis Subzone. 5 Lenticulina polygonata, M-422-16-193, lower Bajocian, Laeviuscula Biozone, Ovalis Subzone. 6 Lenticulina quenstedti, M-402-17-194, lower Bajocian, Laeviuscula Biozone, Ovalis Subzone. 7 Saracenaria cornucopiae, M-402-18-196, lower Bajocian, Laeviuscula Biozone, Ovalis Subzone. 8 Astacolus ef. A. brevispirus, M-402-19-197, lower Bajocian, Laeviuscula Biozone, Ovalis 
Description. Calcitic test, elongated, uniserial, slightly arched, and circular in section. Proloculus is ovate, followed by numerous cylindrical chambers higher than wide, especially the latest ones, that gradually increase in size as added. Test sutures are oblique and constricted in the convex, slightly lobulate margin. Aperture is terminal, radiate, protruding, and located excentrically in the last chamber. Test surface is smooth.

Occurrence and age. Middle Aalenian, Bradfordensis Biozone, Gigantea Subzone-lower Bajocian, Laeviuscula Biozone, Ovalis Subzone (samples M-241-436).

Material. 52 specimens.

Prodentalina subsiliqua (Franke, 1936)

Dentalina subsiliqua Franke, 1936, p. 30, pl. 2, figs. 21a-c.

Description. Calcitic test, elongated, uniserial, and slightly arched with a circular to ovate section. Proloculus ovate, followed by cylindrical chambers initially as high as wide, with the last one higher than wide, that gradually increase in size as added. Sutures are oblique, flush to very slightly depressed; lateral margins of the test are not lobulate. Aperture is terminal, radiate, protruding, and located excentrically in the last chamber. Test surface is smooth.

Remarks. The single specimen found is not illustrated.

Occurrence and age. Upper Aalenian, Concavum Biozone, Concavum Subzone (sample M-273).

Family ROBULOIDIDAE Reiss, 1963

Genus Falsopalmula Bartenstein, 1948

Type species: Flabellina tenuistriata Franke, 1936

Falsopalmula jurensis (Franke, 1936)

Fig. 3.12

Flabellina jurensis Franke, 1936, p. 92, pl. 9, fig. 13.

Description. Calcitic test, elongated, palmate, flattened, and rectangular in section. Proloculus is small, followed by few chambers initially with planispiral-involute coiling. Last 1-4 chambers are uncoiled and develop a symmetrical chevron shape. Sutures are flush to slightly prominent. Aperture is terminal, simple, and located on a short protruding neck in the central part of the last chamber. Test surface is smooth.

Occurrence and age. Upper Aalenian, Concavum Biozone, Concavum Subzone-lower Bajocian, Laeviuscula Biozone, Ovalis Subzone (samples M-273-402).

Material. 34 specimens.

Falsopalmula obliqua (Terquem, 1864)

Fig. 3.13

Flabellina obliqua Terquem, 1864, p. 427, pl. 10, fig. 15.

Description. Calcitic test, elongate, palmate, flattened, and rectangular in section. Proloculus is spherical, followed by 4-5 chambers initially with planispiral-involute coiling; final 1-2 chambers uncoiled and develop an asymmetrical chevron shape, usually with the longer branch toward the proloculus. Sutures are slightly depressed. Apertural area is broken in all specimens. Test surface is smooth.

Occurrence and age. Lower Bajocian, Laeviuscula Biozone, Ovalis Subzone (sample M-402).

Material. Four specimens.

Superfamily NODOSARIACEA Ehrenberg, 1838

Family NODOSARIIDAE Ehrenberg, 1838

Subfamily NODOSARIINAE Ehrenberg, 1838 Genus Nodosaria Lamarck, 1812

Type species: Nautilus radicula Linné, 1758

Nodosaria fontinensis Terquem, 1870a

Fig. 3.14

Nodosaria fontinensis Terquem, 1870a, p. 251, pl. 26, figs. 1-5.

Description. Calcitic test, elongated, straight-uniserial, and circular in section. The spherical proloculus is followed by four chambers, which are slightly higher than wide and increase slowly and regularly in size as added. Sutures are horizontal and depressed, giving rise to lobulate and subparallel lateral margins. Aperture is simple, located in the central part of the last chamber. Surface is covered by 7-10 longitudinal ribs, constricted where they cross the sutures.

Occurrence and age. Upper Aalenian, Concavum Biozone, Concavum Subzone-lower Bajocian, Laeviuscula Biozone, Ovalis Subzone (samples M-273-422).

Material. 15 specimens.

\section{Nodosaria liassica Barnard, 1950}

Fig. 3.15

Nodosaria obscura Reuss var. liassica Barnard, 1950, p. 18, text-figs. $10 \mathrm{a}-\mathrm{c}$.

Description. Calcitic test, elongate, conical, straightuniserial, and circular in section. The spherical proloculus is followed by chambers wider than high, overlapping the preceding one and increasing slowly in size as added, causing the lateral margins to be subparallel to divergent. Sutures are horizontal and flush. Aperture is simple, located in the central part of the last chamber on a little protuberance. Surface is covered by 8-10 longitudinal, acute, and continuous ribs, commonly interrupted before reaching the aperture.

Occurrence and age. Lower Bajocian, Laeviuscula Biozone, Ovalis Subzone (sample M-402).

Material. Three specimens.

Nodosaria nuda Terquem, 1886

Fig. 3.16

Nodosaria nuda Terquem, 1886, p. 11, 12, figs. 25, 26.

Description. Calcitic test, elongate, straight-uniserial, and circular in section. Spherical proloculus is followed by chambers that are slightly higher than wide, with a slow increase in size as added. Sutures are horizontal and

$\leftarrow$

Subzone. 9 Astacolus dorbignyi, M-273-1330, upper Aalenian, Concavum Biozone, Concavum Subzone. 10 Astacolus scalptus, M-402-20-198, lower Bajocian, Laeviuscula Biozone, Ovalis Subzone. 11 Astacolus varians, M-422-13-308, lower Bajocian, Laeviuscula Biozone, Ovalis Subzone. 12 Astacolus sp.: a, lateral view, b, apertural view, M-291-14-309, upper Aalenian, Concavum Biozone, Limitatum Subzone. 13 Marginulina scapha, M402-22-200, lower Bajocian, Laeviuscula Biozone, Ovalis Subzone. 
depressed. Lateral margins are lobulate and subparallel. Aperture is simple and located in the central part of the last chamber. Test surface is smooth.

Occurrence and age. Lower Bajocian, Laeviuscula Biozone, Ovalis Subzone (sample M-402).

Material. Seven specimens.

\section{Nodosaria opalini Bartenstein, 1937}

Fig. 3.17

Nodosaria opalini Bartenstein in Bartenstein and Brand, 1937, p. 147, pl. 8, figs. 13a, b, pl. 10, figs. 18a, b, text-fig. 7 .

Description. Calcitic test, elongate and straight-uniserial, circular in section. Proloculus and aperture are not preserved in the studied specimens. Chambers are ovate, $2 \times$ higher than wide, with a slow increase in size as added. Sutures are horizontal and very depressed, making the lateral margins strongly lobulate and subparallel. Test surface is covered by 15-16 delicate, longitudinal ribs, constricted where they cross the sutures.

Occurrence and age. Upper Aalenian, Concavum Biozone, Concavum Subzone-Limitatum Subzone (samples M-273-291).

Material. Four specimens.

Nodosaria plicatilis Wiśniowski, 1890

Fig. 3.18

Nodosaria plicatilis Wiśniowski, 1890, p. 194, pl. 8, fig. 16.

Description. Calcitic test, elongate, straight-uniserial, and circular in section. Proloculus and aperture are not preserved in the studied material. Chambers are higher than wide, especially in the upper part of the test, and show a regular increase in size with growth. Sutures are horizontal and depressed, giving rise to divergent and lobulate lateral margins. Surface is covered by 9-11 longitudinal ribs, constricted where they cross the sutures.

Occurrence and age. Lower Bajocian, Discites BiozoneLaeviuscula Biozone, Ovalis Subzone (samples M-352-436).

Material. Six specimens.

\section{Nodosaria pseudoregularis Canales, 2001}

Fig. 3.19

Nodosaria pseudoregularis Canales, 2001, p. 300-303, pl. 9, figs. 1-14.

Description. Calcitic test, elongate, straight-uniserial, and circular in section. Proloculus and aperture are not preserved in the studied material. Chambers are spherical, with a small but regular and gradual increase in diameter as added. Sutures are horizontal, broad, and strongly depressed, as necks, giving rise to very lobulate and subparallel lateral margins. Test surface is smooth.

Occurrence and age. Middle Aalenian, Bradfordensis Biozone, Gigantea Subzone-lower Bajocian, Discites Biozone (samples M-241-363).

Material. 21 specimens.

\section{Nodosaria pulchra (Franke, 1936)}

Fig. 3.20

Glandulina pulchra Franke, 1936, p. 59, pl. 6, fig. 4.

Description. Calcitic test, elongate, straight-uniserial, conical in shape, and circular in section. Spherical proloculus is followed by few chambers, wider than high, each overlapping the preceding one and increasing regularly in size as added. Sutures are horizontal and flush to slightly depressed; consequently, lateral margins are straight and divergent. Aperture is rounded, located on a little protuberance in the central part of the last inflated chamber. Surface is ornamented by $7-13$ strong ribs, discontinuous from one chamber to the next, and usually not reaching the aperture.

Occurrence and age. Upper Aalenian, Concavum Biozone, Concavum Subzone-lower Bajocian, Discites Biozone (samples M-273-363).

Material. 21 specimens.

Genus Pseudonodosaria Boomgaart, 1949

Type species: Glandulina discreta Reuss, 1850

Pseudonodosaria vulgata (Bornemann, 1854)

Fig. 3.21

Glandulina vulgata Bornemann, 1854, p. 31, pl. 2, figs. 1a, b, 2.

Description. Calcitic test, straight-uniserial, and circular in section, showing highly variable shape, but frequently cylindrical to conical. Spherical proloculus is followed by a low number of chambers, wider than high, initially strongly overlapping, and rapidly increasing in size, later growing more slowly. Usually the last chamber is inflated. Sutures are horizontal, straight, flush-slightly depressed. Aperture is radiate and located in the central part of the last chamber, sometimes on a small protuberance. Test surface is smooth.

Occurrence and age. Middle Aalenian, Bradfordensis Biozone, Gigantea Subzone-lower Bajocian, Laeviuscula Biozone, Ovalis Subzone (samples M-241-402).

Material. 15 specimens.

Subfamily FRONDICULARIINAE Reuss, 1860

Genus Frondicularia Defrance in d'Orbigny, 1826

Type species: Renulina complanata Defrance in de Blainville, 1824

Frondicularia oolithica Terquem, 1870a

Fig. 3.22

Frondicularia oolithica Terquem, 1870a, p. 213, 214, pl. 22, figs. 1-6.

Description. Calcitic test, elongate and flattened, ovoid in section. Proloculus is not preserved in the studied specimens. Uniserial chambers are low, wider than high, and grow slowly in size as added. Sutures are strongly arched at the midline of the test, slightly prominent as ribbons. Lateral margins are straight and subparallel. Aperture is terminal, ovate, and located in the central part of the last chamber. Test surface is smooth between sutural ribbons.

Occurrence and age. Lower Bajocian, Discites Biozone (sample M-352).

Material. Two specimens.

Family VAGINULINIDAE Reuss, 1860

Subfamily LENTICULININAE Chapman, Parr and Collins, 1934

Genus Lenticulina Lamarck, 1804

Type species: Lenticulites rotulatus Lamarck, 1804

Lenticulina constricta (Kaptarenko-Chernousova), 1961

Fig. 4.1

Planularia constricta Kaptarenko-Chernousova., 1961, p. 75, pl. 11, figs. $6 \mathrm{a}-\mathrm{c}, 7 \mathrm{a}-\mathrm{c}$.

Description. Calcitic test, planispiral, involute, slightly biconvex in section. Concealed proloculus is followed by 
wider than high chambers, 10-11 in the last whorl, increasing progressively in size as added. Sutures are flush, radiate, initially arched, the last ones straight. Apertural face is triangular, compressed, and high. Aperture is radiate and located at the peripheral angle of the last chamber. Peripheral keel is present but usually does not reach the last chamber. Umbonal boss is poorly developed. Test surface is smooth.

Occurrence and age. Middle Aalenian, Bradfordensis Biozone, Gigantea Subzone-lower Bajocian, Laeviuscula Biozone, Ovalis Subzone (samples M-241-422).

Material. 93 specimens.

\section{Lenticulina exgaleata Dieni, 1985}

Fig. 4.2

Lenticulina exgaleata Dieni, 1985, p. 343.

Description. Calcitic test, planispiral, involute, biconvex in section. Concealed proloculus is followed by wider than high chambers, more convex in the lower part than at the periphery, 6-8 in the last whorl, increasing progressively in size as added. Sutures are radiate, arched, elevated, broader in the umbilical zone than at the peripheral margin, and converge in the umbilical region but without a boss. Apertural face is triangular, small, broad, and convex in the lower part. Aperture is radiate and located at the peripheral angle of the last chamber. Peripheral keel usually does not reach the last chamber.

Occurrence and age. Middle Aalenian, Bradfordensis Biozone, Gigantea Subzone-lower Bajocian, Laeviuscula Biozone, Ovalis Subzone (samples M-241-436).

Material. 151 specimens.

\section{Lenticulina helios (Terquem, 1870b)}

Fig. 4.3

Cristellaria helios Terquem, 1870b, p. 183, pl. 16, figs. 19-21.

Description. Calcitic test, planispiral, involute, and biconvex in section. Proloculus is not visible, followed by triangular chambers wider than high, 7-11 in the last whorl, increasing progressively in size as added. Sutures are prominent, radiate, broad, arched towards the preceding chamber, and converge in a prominent umbonal boss. Apertural face is small and triangular. Aperture is radiate and located at the peripheral angle of the last chamber. Peripheral keel usually does not reach the last chamber.

Occurrence and age. Middle Aalenian, Bradfordensis Biozone, Gigantea Subzone-lower Bajocian, Laeviuscula Biozone, Ovalis Subzone (samples M-241-436).

Material. 507 specimens.

\section{Lenticulina muensteri (Roemer, 1839)}

Fig. 4.4

Robulina münsteri Roemer, 1839, p. 48, pl. 20, figs. 29a, b.

Description. Calcitic test, planispiral, involute, and strongly biconvex in section. Proloculus is not visible, followed by chambers wider than high, triangular in section, 12-14 in the last whorl, increasing slowly in size as added. Sutures are flush, radiate, and straight, converging in a very prominent umbilical boss. Apertural face is small and triangular. Aperture is radiate and located at the peripheral angle of the last chamber. Peripheral margin is acute or keeled. Except for the umbonal boss, the test surface is smooth.

Occurrence and age. Middle Aalenian, Bradfordensis Biozone, Gigantea Subzone-lower Bajocian, Laeviuscula Biozone, Ovalis Subzone (samples M-241-436).

Material. 760 specimens.

Lenticulina polygonata (Franke, 1936) Fig. 4.5

Cristellaria (Lenticulina) polygonata Franke, 1936, p. 118, pl. 12, figs. 1, 2.

Description. Calcitic test, planispiral, involute, and biconvex in section. From a lateral view, the last chambers show a polygonal shape. Proloculus is not visible, followed by triangular chambers wider than high, 7-11 in the last whorl, increasing progressively in size as added. Sutures are flush or slightly prominent, radiate, initially arched towards the preceding chamber, but finally straight and converge in a small umbonal boss. Apertural face is small and triangular. Aperture is radiate and located at the peripheral angle of the last chamber. Peripheral keel usually does not reach the last chamber.

Occurrence and age. Middle Aalenian, Bradfordensis Biozone, Gigantea Subzone-lower Bajocian, Laeviuscula Biozone, Ovalis Subzone (samples M-241-436).

Material. 174 specimens.

\section{Lenticulina quenstedti (Gümbel, 1862)}

Fig. 4.6

Cristellaria quenstedti Gümbel, 1862, p. 226, pl. 4, figs. 2a, b.

Description. Calcitic test, planispiral, involute, biconvex in section. Proloculus is not visible, followed by chambers wider than high, triangular in section, convex in the lower part, 7-8 in the last whorl, increasing progressively in size as added. Sutures are prominent, acute, radiate, arched towards the preceding chamber, and converge in the umbilical region, where an acute ring is developed. Apertural face is triangular, high, and convex in its lower part. Aperture is radiate and located at the peripheral angle of the last chamber. Periphery has an acute keel.

Occurrence and age. Middle Aalenian, Bradfordensis Biozone, Gigantea Subzone-lower Bajocian, Laeviuscula Biozone, Ovalis Subzone (samples M-241-436).

Material. 441 specimens.

Genus Saracenaria Defrance, 1824

Type species: Saracenaria italica Defrance, 1824

Saracenaria cornucopiae (Schwager, 1865)

Fig. 4.7

Cristellaria cornucopiae Schwager, 1865, p. 121, pl. 5, figs. 7a, b.

Description. Calcitic test, planispirally coiled and biconvex in section in the early stage, later uniserial and tending to become rectilinear and triangular in section. Proloculus is not visible, followed initially by at least 5-6 planispirally coiled chambers and then by 2-3 uniserial and arched chambers, all of them broader than high, and increasing progressively in size as added. Sutures are flush to slightly depressed, radial, arched in the coiled part of the test but oblique in the uncoiled part. Apertural face is broad and triangular. Aperture is radiate and located in the dorsal angle of the last chamber. Periphery is acute or keeled. Test surface is smooth. 
Occurrence and age. Lower Bajocian, Discites BiozoneLaeviuscula Biozone, Ovalis Subzone (samples M-336-402). Material. Nine specimens.

Subfamily MARGINULININAE Wedekind, 1937 Genus Astacolus de Montfort, 1808

Type species: Astacolus crepidulatus de Montfort, 1808

Astacolus cf. A. brevispirus (Wiśniowski, 1890) Fig. 4.8

Cristellaria brevispira Wiśniowski, 1890, p. 228, pl. 10, figs. 6a, b.

Description. Calcitic test, elongate, flattened, and ovate in section. Proloculus is not visible, followed by 4-5 low, broad chambers that are initially planispiral but become uncoiled, uniserial, and arched in the last 1-3; all of them are wider than high and show a regular increase in size as added. Last chamber is larger than the preceding ones. Sutures are flush to slightly depressed, radial, and arched in the planispiral part of the test, later oblique. Apertural face is broad and high, slightly convex in its lower part. Aperture is radiate and located in the dorsal angle of the last chamber. Periphery is acute or keeled. Test surface is smooth.

Remarks. The scarce Murtinheira specimens that differ in some respects from Wiśniowski's (1890) type material account for the "cf." assignment to A. brevispirus. These differences include a higher chamber number in the uncoiled part of the test, a less developed final chamber, and a periphery that is not always keeled.

Occurrence and age. Lower Bajocian, Laeviuscula Biozone, Ovalis Subzone (sample M-402).

Material. Four specimens.

\section{Astacolus dorbignyi (Roemer, 1839)}

Fig. 4.9

Peneroplis dorbignii Roemer, 1839, p. 47, pl. 20, figs. 31a, b.

Description. Calcitic test, elongate, slightly flattened, and ovate in section. Proloculus is not visible, followed by low, broad chambers, triangular in section, that are planispirally coiled through the first seven or fewer chambers and become uncoiled, uniserial, and slightly arched in the last 14; all of them increase regularly in size as added. Sutures are acute, initially radial and arched, later oblique. Apertural face is triangular, long, and slightly convex. Aperture is radiate and located in the dorsal angle of the last chamber. Test surface is covered by reticulated ornamentation, resulting from the intersection of the acute sutures with up to 10 longitudinal acute ribs. Periphery is keeled.

Occurrence and age. Upper Aalenian, Concavum Biozone, Concavum Subzone-Limitatum Subzone (samples M-269-291).

Material. 11 specimens.

Astacolus scalptus (Franke, 1936)

Fig. 4.10

Cristellaria (Astacolus) scalpta Franke, 1936, p. 105, 106, pl. 10, figs. 19, 20a, b.

Description. Calcitic test, elongate, flattened, and ovate in section. Proloculus is not visible, followed by low, broad chambers, triangular in section, inflated, the initial 6-8 planispiral, later 1-3 uncoiled, uniserial, and slightly arched; all of them increase regularly in size as added.
Sutures are arched and depressed, radial in the coiled part of the test, later oblique. Apertural face is triangular, long, and slightly convex. Aperture is radiate, prominent, and located in the dorsal angle of the last chamber. The peripheral keel usually does not reach the last chamber. Test surface is smooth.

Occurrence and age. Middle Aalenian, Bradfordensis Biozone, Gigantea Subzone-lower Bajocian, Laeviuscula Biozone, Ovalis Subzone (samples M-241-436).

Material. 229 specimens.

\section{Astacolus varians (Bornemann, 1854)}

Fig. 4.11

Cristellaria varians Bornemann, 1854, p. 41, pl. 4, figs. 32a, b, 33a, b, $34 \mathrm{a}, \mathrm{b}$.

Description. Calcitic test, elongate, flattened, and ovate in section. Proloculus is not visible, followed by 7-8 low, broad, planispirally coiled chambers, triangular in section, later tending to uncoil and becoming slightly arched; all of them increase regularly in size as added. Sutures are arched, usually flush, sometimes slightly prominent, and converge in a small boss in the umbilical region. Apertural face is triangular and long. Aperture is radiate and located in the dorsal angle of the last chamber. Periphery is acute, sometimes showing a keel that usually does not reach the last chamber. Test surface is smooth.

Occurrence and age. Upper Aalenian, Concavum Biozone, Concavum Subzone-lower Bajocian, Laeviuscula Biozone, Ovalis Subzone (samples M-273-422).

Material. 19 specimens.

\section{Astacolus sp}

Fig. 4.12

Astacolus sp. 1 of Canales, 2001, p. 331, 332, pl. 5, figs. 8, 9.

Description. Calcitic test, elongate and flattened. Proloculus is not visible, followed initially by 6-7 low, broad, planispirally coiled chambers, triangular in section, and then 1-2 arched ones; all of them increase progressively in size as added. Sutures are radiate, arched, elevated, broader in the umbilical zone than in the peripheral margin, and converge in the umbilical region without an umbonal boss. Apertural face is triangular, broad, and very convex in the lower part. Aperture is radiate and located at the peripheral angle of the last chamber. Periphery is acute, sometimes keeled.

Remarks. Astacolus sp. is very similar to Lenticulina exgaleata Dieni except that the last chambers clearly tend to uncoil.

Occurrence and age. Middle Aalenian, Bradfordensis Biozone, Gigantea Subzone-upper Aalenian, Concavum Biozone, Limitatum Subzone (samples M-241-291).

Material. 17 specimens.

Genus Marginulina d'Orbigny, 1826

Type species: Marginulina raphanus d'Orbigny, 1826

\section{Marginulina scapha Lalicker, 1950}

Fig. 4.13

Marginulina scapha Lalicker, 1950, p. 12, pl. 1, figs. 7a, b.

Description. Calcitic test, elongate, flattened, and ovate in section. Proloculus is not visible, followed by a very short, curved early stage. Final 5-7 chambers are uniserial, almost rectilinear. All chambers increase progressively in size as 


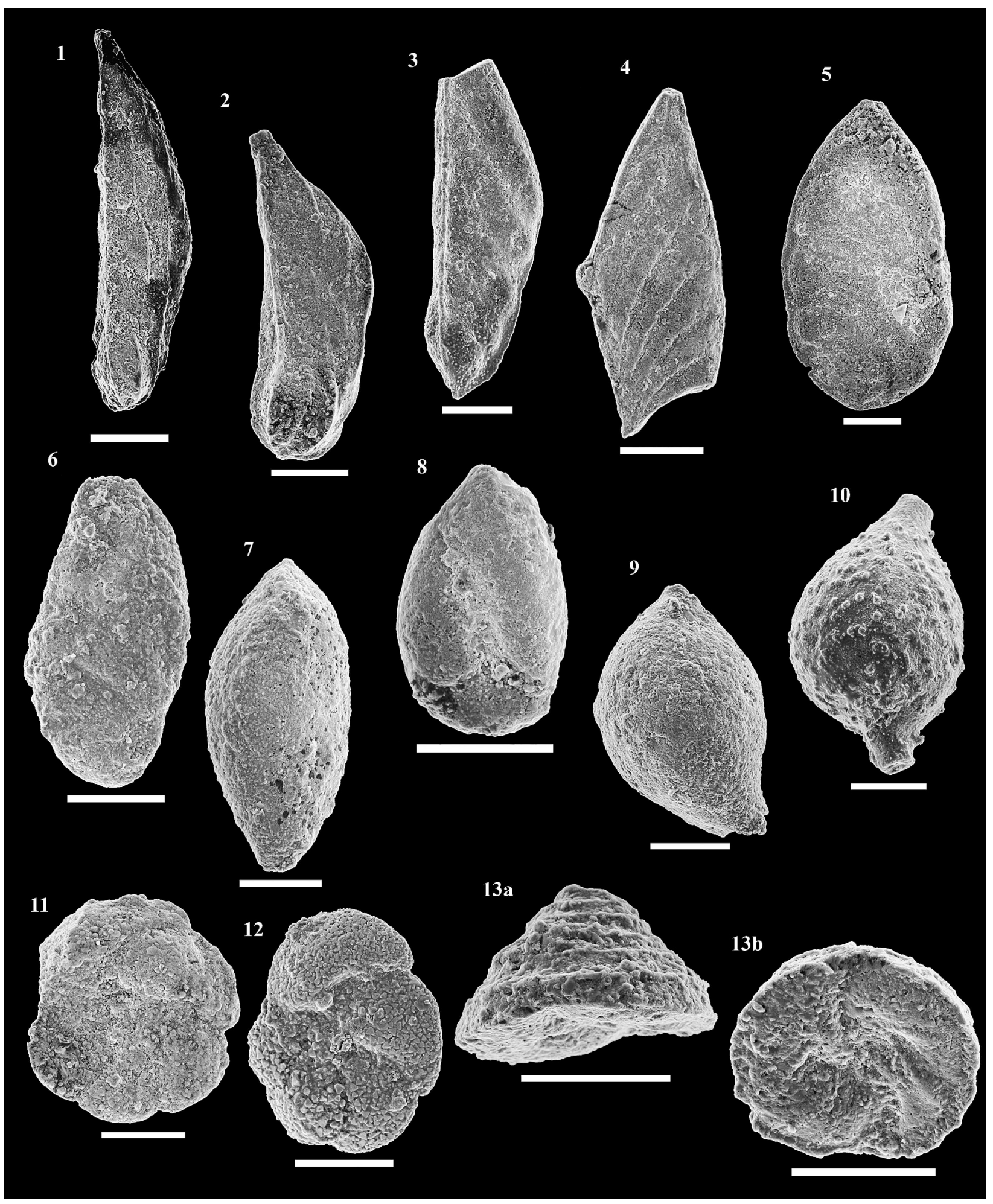

FIGURE 5. Selected Bajocian GSSP foraminifers corresponding to the suborders Lagenina, Robertinina, and Rotaliina in the Murtinheira section. Scale bars $=100 \mu \mathrm{m} .1$ Citharina colliezi, M-291-1349, upper Aalenian, Concavum Biozone, Limitatum Subzone. 2 Citharina ornithocephala, M-40236-120, lower Bajocian, Laeviuscula Biozone, Ovalis Subzone. 3 Citharina sagittiformis, M-402-32-259, lower Bajocian, Laeviuscula Biozone, Ovalis Subzone. 4 Planularia beierana, M-402-23-201, lower Bajocian, Laeviuscula Biozone, Ovalis Subzone. 5 Planularia cordiformis, M-402-24-202, lower Bajocian, Laeviuscula Biozone, Ovalis Subzone. 6 Planularia protracta, M-402-16-312, lower Bajocian, Laeviuscula Biozone, Ovalis Subzone. 7 Eoguttulina liassica, M-363-26-204, lower Bajocian, Discites Biozone. 8 Eoguttulina oolithica, M-386-27-205, lower Bajocian, Discites Biozone. 9 Bullopora rostrata, M-402-46-173, lower Bajocian, Laeviuscula Biozone, Ovalis Subzone. 10 Ramulina spandeli, M-402-11-93, lower Bajocian, Laeviuscula Biozone, Ovalis Subzone. 11 Ceratobuliminidae indet., dorsal view, M-363-41-125, lower Bajocian, Discites Biozone. 12 Ceratobuliminidae indet., umbilical view, M-283-19-315, upper Aalenian, Concavum Biozone, Concavum Subzone. 13 Paalzowella goyi: a, lateral view, M-402-42-127; b, apertural side, M-402-42-126; lower Bajocian, Laeviuscula Biozone, Ovalis Subzone. 
added; consequently, lateral margins are divergent. Sutures are oblique and slightly depressed. Aperture is radiate and located at the dorsal angle of the last chamber. Test surface is smooth. Periphery is keeled.

Occurrence and age. Lower Bajocian, Laeviuscula Biozone, Ovalis Subzone (samples M-402-436).

Material. Seven specimens.

Subfamily VAGINULININAE Reuss, 1860 Genus Citharina d'Orbigny, 1839

Type species: Vaginulina (Citharina) strigillata Reuss, 1846 Citharina colliezi (Terquem, 1866)

Fig. 5.1

Marginulina colliezi Terquem, 1866, p. 430, 431, pl. 17, figs. 10a-c.

Description. Calcitic test, triangular in outline, and strongly flattened. Proloculus is ovate, followed by a relatively high number of uniserial chambers, broader than high, angled toward the proloculus, and increasing progressively in size as added. Dorsal margin is straight with a continuous longitudinal rib, perpendicular to the test surface; the ventral margin is divergent and lobulate. Sutures are oblique and slightly depressed. Aperture is radiate and located in the dorsal angle of the last chamber. Surface is ornamented by numerous, regularly spaced, and discontinuous longitudinal ribs.

Occurrence and age. Upper Aalenian, Concavum Biozone, Concavum Subzone-Limitatum Subzone (samples M-273-291).

Material. Three specimens.

Citharina ornithocephala (Wiśniowski, 1890)

Fig. 5.2

Vaginulina ornithocephala Wiśniowski, 1890, p. 210, pl. 9, figs. 1a, b.

Description. Calcitic test, small, triangular in outline, and strongly flattened. Proloculus is spherical and very large, followed by 3-4 uniserial chambers, broader than high, angled from the dorsal to the ventral margin, and increasing slowly in size as added. Dorsal margin is straight or slightly arched, with a continuous longitudinal rib less prominent in the last chambers, and the ventral margin is slightly divergent and lobulate. Sutures are oblique and depressed. Aperture is radiate and located on a protuberance in the dorsal angle of the last chamber. Surface is ornamented by scarce, discontinuous longitudinal ribs.

Occurrence and age. Lower Bajocian, Laeviuscula Biozone, Ovalis Subzone (samples M-402-436).

Material. 11 specimens.

Citharina sagittiformis (Terquem, 1868)

Fig. 5.3

Marginulina sagittiformis Terquem, 1868, p. 76, pl. 3, figs. 1a-c.

Description. Calcitic test, triangular in outline, and strongly flattened. Proloculus is ovate, followed by 4-5 uniserial chambers, broader than high, angled from the dorsal to the ventral margin, and increasing regularly in size as added. Dorsal margin is straight, with a continuous longitudinal rib perpendicular to the test surface and a peripheral keel; the ventral margin is slightly divergent, also with an acute keel. Sutures are oblique and depressed. Apertural area is broken in the only recovered specimen. Test surface is smooth.
Occurrence and age. Lower Bajocian, Laeviuscula Biozone, Ovalis Subzone (sample M-402).

Genus Planularia Defrance, 1826

Type species: Peneroplis auris Defrance in de Blainville, 1824

Planularia beierana (Gümbel, 1862)

Fig. 5.4

Marginulina beierana Gümbel, 1862, p. 221, 222, pl. 3, figs. 20a, b.

Description. Calcitic test, triangular in outline, and strongly compressed. Proloculus is small and spherical, followed by 7-8 uniserial chambers, broader than high, angled from the dorsal to the ventral margin, and increasing in size as added. Dorsal margin is slightly arched, and ventral margin is divergent. Sutures are oblique from the dorsal to the ventral margin, depressed, or slightly elevated. Aperture is radiate and located in the dorsal angle of the last chamber on a little protuberance. Test surface is smooth between sutures.

Occurrence and age. Lower Bajocian, Discites BiozoneLaeviuscula Biozone, Ovalis Subzone (samples M-355402).

Material. Six specimens.

Planularia aff. P. beierana (Gümbel, 1862)

Marginulina beierana Gümbel, 1862, p. 221, 222, pl. 3, figs. 20a, b.

Remarks. All the specimens are broken. The fragments display features more similar to $P$. beierana (Gümbel) than to any other Planularia, but it is impossible to attribute them definitely to this species because their complete morphologies cannot be observed. No specimens are illustrated.

Occurrence and age. Middle Aalenian, Bradfordensis Biozone, Gigantea Subzone-upper Aalenian, Concavum Biozone, Limitatum Subzone (samples M-241-306).

Material. Five specimens.

Planularia cordiformis (Terquem, 1863)

Fig. 5.5

Cristellaria cordiformis Terquem, 1863, p. 203, pl. 9, figs. 14a, b.

Description. Calcitic test, ovate in outline, and strongly compressed. Proloculus is small and ovate, followed by $6-$ 8 uniserial chambers, broader than high, acutely angled from the dorsal to the ventral margin, tending to reach the proloculus, and increasing in size as added. Dorsal margin is arched and ventral margin is slightly lobulate. Sutures are oblique from the dorsal to the ventral margin, flush to slightly depressed. Aperture is radiate and located in the dorsal angle of the last chamber. Test surface is smooth.

Occurrence and age. Upper Aalenian, Concavum Biozone, Concavum Subzone-lower Bajocian, Laeviuscula Biozone, Ovalis Subzone (samples M-273-402).

Material. 15 specimens.

Planularia cf. P. eugenii (Terquem, 1864)

Cristellaria engenii Terquem, 1864, p. 414, pl. 9, figs. 16a, b.

Description. Calcitic test, elongate, slightly arched, compressed, and ovate in section. Proloculus is small and ovate, followed by six chambers, broader than high, except for the last one that is higher than broad and prominent. 
They increase regularly in size as added. Sutures are straight, oblique, and depressed; consequently, lateral margins are slightly divergent and lobulate. Aperture is located in the dorsal angle of the last chamber on a protuberance. Surface is covered by numerous, delicate ribs.

Remarks. The only recovered specimen shows morphological features very similar to $P$. eugenii (Terquem), but differs from this species in having a less compressed and initially flatter test. In addition, the test surface is recrystallized, obscuring the ornamentation. The specimen is not illustrated.

Occurrence and age. Upper Aalenian, Concavum Biozone, Concavum Subzone (sample M-273).

\section{Planularia protracta (Bornemann, 1854)}

Fig. 5.6

Cristellaria protracta Bornemann, 1854, p. 39, pl. 4, figs. 27a, b.

Description. Calcitic test, elongate, compressed, ovate in section. Proloculus is ovate, followed by 6-8 uniserial chambers, slightly broader than high, angled from the dorsal to the ventral margin, and increasing regularly in size as added. Dorsal margin is slightly arched and ventral margin is slightly lobulate. Sutures are oblique from the dorsal to the ventral margin, flush to depressed. Aperture is radiate and located in the dorsal angle of the last chamber. Test surface is smooth.

Occurrence and age. Upper Aalenian, Concavum Biozone, Concavum Subzone-lower Bajocian, Laeviuscula Biozone, Ovalis Subzone (samples M-273-422).

Material. 16 specimens.

Family POLYMORPHINIDAE d'Orbigny, 1839

Subfamily POLYPMORPHININAE d'Orbigny, 1839

Genus Eoguttulina Cushman and Ozawa, 1930

Type species: Eoguttulina anglica Cushman and Ozawa, 1930

\section{Eoguttulina liassica (Strickland, 1846)}

Fig. 5.7

Polymorphina liassica Strickland, 1846, p. 31, fig. 6.

Description. Calcitic test, elongate, straight, and circular in section. Proloculus is spherical followed by chambers (3/ whorl) with "polymorphinid" arrangement, elongate, and slightly inflated, increasing regularly in size as added and overlapping the preceding ones. Sutures are slightly depressed and oblique. Aperture is radiate and located in the upper part of the test. Test surface is smooth.

Occurrence and age. Upper Aalenian, Concavum Biozone, Concavum Subzone-lower Bajocian, Laeviuscula Biozone, Ovalis Subzone (samples M-273-436).

Material. 48 specimens.

\section{Eoguttulina oolithica (Terquem, 1874)}

Fig. 5.8

Polymorphina oolithica Terquem, 1874, p. 299, pl. 32, figs. 1-10.

Description. Calcitic test, elongate, straight, broad, and ovate in section. Proloculus is not visible, followed by chambers (3/whorl) with "polymorphinid" arrangement, elongate, very inflated, increasing regularly in size as added, and strongly overlapping the preceding ones. Sutures are depressed and oblique. Aperture is radiate and located in the upper part of the test. Test surface is smooth.
Occurrence and age. Lower Bajocian, Discites Biozone (sample M-386).

Material. One specimen.

Eoguttulina cf. E. oolithica (Terquem, 1874)

Polymorphina oolithica Terquem, 1874, p. 299, pl. 32, figs. 1-10.

Remarks. Only a single specimen is assigned to this taxon. It displays features generally similar to E. oolithica (Terquem), being broader and having more highly inflated chambers than E. liassica (Strickland). However, the recrystallized test hinders observation of the detailed morphological characters that would allow precise identification. The specimen is not illustrated.

Occurrence and age. Lower Bajocian, Discites Biozone (sample M-352).

Subfamily WEBBINELLINAE Rhumbler, 1904 Genus Bullopora Quenstedt, 1856

Type species: Bullopora rostrata Quenstedt, 1857

Bullopora rostrata Quenstedt, 1857

Fig. 5.9

Bullopora rostrata Quenstedt, 1857, p. 580, pl. 73, fig. 28.

Description. Calcitic test, attached, composed of uniserial hemispherical chambers, slightly higher than broad, ovate in outline, added in an irregular fashion, and increasing slowly in size as added. Sutures are broad and strongly depressed, as long necks. Aperture is not preserved in the studied specimens. Test surface is smooth.

Occurrence and age. Lower Bajocian, Laeviuscula Biozone, Ovalis Subzone (sample M-402).

Material. Two specimens.

Genus Ramulina Jones, 1875

Type species: Ramulina laevis Jones in Wright, 1875

Ramulina spandeli Paalzow, 1917

Fig. 5.10

Ramulina spandeli Paalzow, 1917, p. 246, pl. 47, fig. 15.

Description. Calcitic test, uniserial. Proloculus is not preserved in the studied specimens. Chambers are ovate, higher than broad. Sutures are broad and strongly depressed, giving rise to long necks between chambers. Aperture is obscure but located excentrically in the last chamber at the end of a protuberance. Surface is hispid, covered by numerous little spines.

Occurrence and age. Lower Bajocian, Discites BiozoneLaeviuscula Biozone, Ovalis Subzone (samples M-352436).

Material. 33 specimens.

Suborder ROBERTININA Loeblich and Tappan, 1984

Superfamily CERATOBULIMINACEA Cushman, 1927 Family CERATOBULIMINIDAE Cushman, 1927

Ceratobuliminidae indet.

Figs. 5.11, 5.12

Description. Specimens are internal molds of iron oxide or pyrite that show trochospirally coiled chambers, evolute in spiral view and involute in umbilical view. They are convex dorsally and flat-concave on the umbilical side, ovoid to circular in shape, and lobulate. Trapezoidal chambers of variable number occur in the last whorl, increasing gradually in size as added. Sutures are radial and arched. 
Remarks. A precise identification is not possible due to the absence of diagnostic morphological features.

Occurrence and age. Middle Aalenian, Bradfordensis Biozone, Gigantea Subzone-lower Bajocian, Laeviuscula Biozone, Ovalis Subzone (samples M-241-402).

Material. Seven specimens.

Subfamily REINHOLDELLINAE Seiglie and Bermúdez, 1965

Genus Larmarckella Kaptarenko-Chernousova, 1956

Type species: Lamarckella media Kaptarenko-Chernousova, 1956

Lamarckella inflecta Kaptarenko-Chernousova, 1956

Lamarckella inflecta Kaptarenko-Chernousova, 1956, p. 59, pl. 1, fig. 5, pl. 11, figs. 12, 13a-c.

Description. Very small test, convex in dorsal view, flat to very slightly convex in ventral view, and circular in shape. Chambers (5-6 in the last whorl) are trapezoidal on the dorsal side, and increase regularly in size as added. On the ventral side they are involute and visible only in the last whorl. Sutures are straight, oblique, and flush to slightly depressed. Aperture opens umbically in the middle part of the base of the last chamber. Test surface is smooth.

Remarks. No specimens are illustrated because strong test recrystallization makes it difficult to obtain good SEM photographs.

Occurrence and age. Lower Bajocian, Discites BiozoneLaeviuscula Biozone, Ovalis Subzone (samples M-352-402). Material. 21 specimens.

Genus Reinholdella Brotzen, 1948

Type species: Discorbis dreheri Bartenstein in Bartenstein and Brand, 1937

Reinholdella dreheri (Bartenstein, 1937)

Discorbis dreheri Bartenstein in Bartenstein and Brand, 1937, p. 192, pl. 6, figs. $45 \mathrm{a}, \mathrm{b}$, pl. 8 , figs. $42 \mathrm{a}-\mathrm{e}, \mathrm{pl} .10$, figs. $47 \mathrm{a}-\mathrm{d}$.

Description. Convex test in dorsal view, flat to concave in umbilical view, circular in shape, with 2-3 low, trochospiral whorls. Chambers are trapezoidal and slightly inflated, evolute in dorsal view and involute on umbilical side, increasing regularly in size as added, with $\sim 5-6$ chambers in the last whorl. Sutures in dorsal view are straight, oblique, and flush to slightly depressed, and the periphery is lobulate. Aperture is located in the umbilical side. Test surface is smooth.

Remarks. No specimens are illustrated because strong test recrystallization makes it difficult to obtain good SEM photographs.

Occurrence and age. Middle Aalenian, Bradfordensis Biozone, Gigantea Subzone-lower Bajocian, Laeviuscula Biozone, Ovalis Subzone (samples M-241-436).

Material. 45 specimens.

Suborder ROTALIINA Delage and Hérouard, 1896 Superfamily DISCORBACEA Ehrenberg, 1838

Family PLACENTULINIDAE Kasimova and others, 1980

Subfamily ASHBROOKINAE Loeblich and Tappan, 1984

Genus Paalzowella Cushman, 1933

Type species: Discorbina scalariformis Paalzow, 1917

Paalzowella goyi Canales, 2001

Fig. 5.13

Paalzowella goyi Canales, 2001, p. 353, 354, pl. 19, figs. 4-10.
Description. Calcitic test, conical, triangular in lateral view, and circular in outline. Proloculus is small and spherical, followed by 4-7 whorls of trochospirally coiled chambers, broader than high, and increasing regularly in size as added. In dorsal view the test is convex, initially with 4-5 chambers/whorl, but with only 2-4 in the last one. Sutures are arched and elevated. In ventral view, the test is flat-concave, showing a small depression in the central part from which 3-4 radial splits develop. Periphery is acute. Aperture is located at the base of the last chamber.

Occurrence and age. Lower Bajocian, Discites BiozoneLaeviuscula Biozone, Ovalis Subzone (samples M-352402).

Material. Four specimens.

\section{Assemblage Descriptions}

\section{Introduction}

Five foraminiferal suborders-Textulariina, Spirillinina, Lagenina, Robertinina, and Rotaliina-were found at the Bajocian GSSP in the Murtinheira section. Except for the assemblage in sample M-269 (upper Aalenian, Concavum Biozone, Concavum Subzone) most specimens belong to the Lagenina genus Lenticulina. Spirillinina specimens are abundant in most lower Bajocian assemblages, whereas representatives of the Textulariina, Robertinina and Rotaliina are minor components throughout. Assemblage compositions are apparently homogeneous, but specimen counts/species vary from sample to sample. The main features of the assemblages are reported in the following sections.

\section{Middle Aalenian, Bradfordensis Biozone, Gigantea Subzone}

Foraminifers obtained from sample M-241 in the upper part of the Gigantea Subzone show low abundance (131 specimens) but relatively high diversity (16 taxa). Most belong to Lenticulina muensteri (36 specimens), L. quenstedti (24), and L. helios (20). The second species, recorded here for the first time at Murtinheira, is an important component in this section.

\section{Upper Aalenian, Concavum Biozone, Concavum and} Limitatum subzones

Sample M-269, located in the lowermost Concavum Subzone immediately above a discontinuity, yielded only three specimens belonging to L. muensteri, Astacolus dorbignyi, and a representative of the family Ceratobuliminidae.

The assemblage in sample M-273 is one of the most abundant (580 specimens) and diverse (26 taxa). Lenticulina is the most abundant genus, represented mostly by $L$. muensteri (164 specimens) and L. quenstedti (96), but also with Astacolus scalptus (48) and a relatively high number (67) of specimens of the suborder Spirillinina. This assemblage records the LOs of Prodentalina subsiliqua and Planularia cf. P. eugenii, whose FOs in this section are in the lower Aalenian, Opalinum Biozone, Comptum Subzone (Canales and Henriques, 2008), and the FOs of Nodosaria opalini and Conicospirillina sp., recognized here for the first 
time in Murtinheira. All other assemblage components occur in the lower Aalenian and upper Toarcian in this section (Canales and Henriques, 2008).

Sample M-283 from the uppermost Concavum Subzone contains a low number of specimens (100) but a relatively high number of taxa (20). Lenticulina species are still the most abundant in this assemblage, and no LO or FO datums are recorded.

The first assemblage corresponding to the Limitatum Subzone comes from sample M-285. It is very similar to the previous sample in displaying a low number of specimens (77) and a relatively high number of taxa (14), without any LO or FO datums. Most specimens belong to different species of Lenticulina that is clearly dominant in this assemblage.

The overlying sample M-291 exhibits a very abundant (755 specimens) and diverse (26 taxa) assemblage. The most abundant species are L. muensteri (198 specimens), $L$. quenstedti (84), Spirillina orbicula (81), and A. scalptus (70). The FO of Reophax agglutinans is recorded, as well as the LOs of $A$. dorbignyi and Citharina colliezi, both typical upper Toarcian and Aalenian taxa. Conicospirillina sp., Nodosaria opalini, and Astacolus sp. are restricted to the upper Aalenian, Concavum Biozone, in Murtinheira.

In the middle part of the Limitatum Subzone, the assemblage from sample M-306 contains a low number of specimens (141) but a relatively high number of taxa (17), all of them recognized in previous assemblages. The most abundant species are L. muensteri (46 specimens), L. helios (20), and A. scalptus (15). Planularia aff. P. beierana, a scarce assemblage component beginning in the lower Aalenian in Murtinheira (Canales and Henriques, 2008), has its LO in this sample.

The highest Limitatum Subzone sample (M-330) has very few specimens (33) and taxa (9). The most abundant species is $S$. orbicula (9 specimens), followed by A. scalptus (8) and L. muensteri (7); no LOs or FOs have been recognized.

\section{Lower Bajocian, Discites Biozone}

The first Bajocian sample (M-336), belonging to the Discites Biozone, yields only 11 specimens and 5 species, with L. muensteri (7 specimens) the most abundant. Saracenaria cornucopiae has its FO at this level.

Foraminifers from sample M-352 are relatively abundant (283 specimens) and diverse (23 taxa). The most abundant species are S. orbicula (85), L. muensteri (62), and L. helios (39). Some typical Middle Jurassic foraminiferal species are recorded here for the first time in Murtinheira, including Frondicularia oolithica and Eoguttulina cf. E. oolithica (both restricted to this assemblage), Lingulonodosaria dentaliniformis, Paalzowella goyi, Lamarckella inflecta, Nodosaria plicatilis, and Ramulina spandeli.

The assemblage obtained from sample M-355 shows a decrease in abundance (91 specimens) and diversity (17 taxa) when compared to the preceding one. Both are very similar taxonomically except for the FO of Planularia beierana in this assemblage. The most abundant species from M-355 are $S$. orbicula (26 specimens) and L. muensteri (21).
Sample M-363, located in the middle of the Discites Biozone, has relatively low foraminiferal abundance (111 specimens) and diversity (20 taxa) comparable to the previous assemblage, but a similar taxonomic composition. The most abundant species are $S$. orbicula (22 specimens), L. muensteri (20), and L. helios (15). Last occurrences include those of Nodosaria pulchra and N. pseudoregularis, which appear in the upper Toarcian at Murtinheira (Canales and Henriques, 2008). The latter species is an abundant and constant component of Aalenian foraminiferal assemblages in this section (Canales, 2001; Canales and Henriques, 2008).

The upper part of the Discites Biozone in sample M-386 shows relatively high foraminiferal abundance (263 specimens) and diversity (22 taxa), with the most abundant species being $S$. orbicula (52), L. quenstedti (50), L. helios (34), and Reophax agglutinans (32). Lingulonodosaria dentaliniformis and $P$. goyi have their LOs in this assemblage, thus restricting their distribution to the Discites Biozone in the Murtinheira section. At the same time Prodentalina intorta, Eoguttulina oolithica, Trochammina sablei, and Conicospirillina conoidea make their FOs, although the first three are present only in this sample.

\section{Lower Bajocian, Laeviuscula Biozone, Ovalis Subzone}

The first sample (M-402) of the Laeviuscula Biozone, Ovalis Subzone, recorded the highest abundance (937 specimens) and diversity (38 taxa) of all samples collected in this section. The most abundant species are $S$. orbicula (160 specimens), R. agglutinans (155), L. helios (143), and L. quenstedti (115). In addition, several LOs and FOs have been recognized. Among the LOs are some species formerly thought to be typically Toarcian and Aalenian (Canales and Henriques, 2008), such as Pseudonodosaria vulgata, Planularia cordiformis, Falsopalmula jurensis, and representatives of the family Ceratobuliminidae. Other LOs restricted to the Aalenian-Bajocian transition or to the lower Bajocian in Murtinheira include $R$. agglutinans, Saracenaria cornucopiae, Lamarckella inflecta, Planularia beierana, and Conicospirillina conoidea. Eleven FOs are recorded in this assemblage: Glomospira gordialis, Prodentalina cf. $P$. guembeli, P. mucronata, Falsopalmula obliqua, Nodosaria liassica, N. nuda, Astacolus cf. A. brevispirus, Citharina sagittiformis, Bullopora rostrata, Marginulina scapha, and Citharina ornithocephala, of which the first nine are limited to this sample.

In contrast, the assemblage obtained from sample M-422 shows relatively low abundance (134 specimens) but relatively high diversity (17 taxa). The most abundant species are L. helios (36 specimens), L. muensteri (26), and S. orbicula (17). Last occurrences include Lenticulina constricta, Nodosaria fontinensis, Planularia protracta, and Astacolus varians. All these species originate in the upper Toarcian or Aalenian at Murtinheira (Canales and Henriques, 2008).

The last assemblage from this subzone (sample M-436) has relatively low abundance (151 specimens) and diversity (16 taxa), with the most abundant species being $S$. orbicula (46), L. muensteri (23), L. helios (22), and L. quenstedti (19). All species in this sample occur in older asemblages. 


\section{BIOSTRATIGRAPHIC REMARKS}

\section{Introduction}

Ammonites are considered the best fossils for dating Jurassic marine sedimentary rocks. However, alternative biostratigraphic scales, based on other fossil groups, are needed when ammonites are absent, scarce, or almost impossible to obtain, as is the case with core and cutting samples. This has led to the establishment of Jurassic biostratigraphic scales based on benthic foraminifers in the last decades (Fig. 6). The validity and precision of such scales are higher when they can be calibrated with accurate biostratigraphic charts based on ammonites, as is the case for the Bajocian GSSP (Henriques, 1992, 1995).

The attempt to establish these biostratigraphic scales are hindered by the wide stratigraphic ranges of most Jurassic foraminiferal species. For this reason, the stratigraphic location of foraminiferal bioevents (such as FOs, LOs, or notable changes in diversity or relative abundance of some taxa) can be a useful biostratigraphic tool, initially of local application due to the close relationship between species and paleoenvironmental conditions. However, studies extended inside the same basin or to other basins will allow the recognition of useful, local or regional, bioevents. The following sections deal with the identification of both biozones and bioevents recognized from the analyses of the foraminiferal assemblages in the Bajocian GSSP.

\section{Foraminiferal Biozones}

The stratigraphic distribution of foraminifers at the Aalenian-Bajocian transition in Murtinheira (Fig. 2) allows the establishment of two biozones: the Lenticulina quenstedti Zone and the Ramulina spandeli Zone (Fig. 6). Both are based on species that are consistently present, relatively abundant, and very easily recognizable so that even a single specimen fragment allows identification.

The lower boundary of the L. quenstedti Zone coincides with the FO of the index species in sample M-241 from the upper part of the Gigantea Subzone, Bradfordensis Biozone, middle Aalenian. The upper boundary coincides with the FO of Ramulina spandeli (Paalzow), the nominal index species of the following foraminiferal biozone established in the Bajocian GSSP.

Gümbel (1862) defined L. quenstedti from lower Oxfordian sedimentary rocks in Bayern (Germany). It is a typical Middle-Upper Jurassic species, frequently found in this stratigraphic interval in Great Britain (Barnard and others, 1981; Coleman, 1981; Morris and Coleman, 1989), France (Wernli, 1971; Wernli and Septfontaine, 1971; El Khanchoufi, 1988; Délance and Ruget, 1989), Italy (Barbieri, 1964), Sweden (Norling, 1972), Portugal (Ruget, 1973; Stam, 1985), Poland (Bielecka, 1960), Canada (Gradstein, 1977), Morocco (Boutakiout, 1990), and Iran (Kalantari, 1969). However, it has also been recognized in the upper Toarcian of Great Britain (Copestake and Johnson, 1989), France (Séronie-Vivien and others, 1961), and Morocco (Oumalch, 1979).

Thirty-two foraminiferal species occur in the L. quenstedti Zone, most having a very wide stratigraphic distribution, even from the upper Toarcian Aalensis
Biozone (Canales and Henriques, 2008). This distribution is especially noticeable for almost all species of Lenticulina and Spirillina, as well as for some of Astacolus and Prodentalina, which are the main components of the assemblages. Moreover, all these species are recognized in assemblages occurring in the overlying foraminiferal biozone.

Only two taxa (Nodosaria opalini and Conicospirillina sp.) at Murtinheira are restricted to the L. quenstedti Zone. Astacolus sp., A. dorbignyi, Planularia aff. P. beierana, $P$. cf. P. eugenii, Prodentalina subsiliqua, and Citharina colliezi have their LOs in this biozone, while Saracenaria cornucopiae and Reophax agglutinans have their FOs. In the Aalenian-Bajocian boundary interval, corresponding to the upper part of the L. quenstedti Zone, the recorded foraminiferal assemblages (M-330 and M-336) are rather impoverished in the number of specimens and taxa, but no LO is found.

The lower boundary of the $R$. spandeli Zone coincides with the FO of the index species in sample M-352 within the lower part of the Discites Biozone, lower Bajocian. The upper boundary is not defined, but the biozone extends at least to sample M-436, the lower part of the Ovalis Subzone, Laeviuscula Biozone, lower Bajocian.

Ramulina spandeli was defined by Paalzow (1917) from Upper Jurassic sedimentary rocks at Würgau (south Germany). It is usually referred to the Middle and Upper Jurassic in Germany (Paalzow, 1932; Seibold and Seibold, 1960) and Poland (Bielecka, 1960), but has also been recorded from the Lower-Upper Jurassic in Germany (Frentzen, 1941) and in the upper Toarcian-lower Aalenian of Poland (Tyszka, 2001).

The $R$. spandeli Zone contains 47 foraminiferal taxa. A clear renewal of the faunas takes place in the lowermost part of this zone following the impoverishment recorded at the Aalenian-Bajocian boundary. Twenty-two FOs of typical Middle Jurassic species are recorded in this biozone. Some of them are scarce and seem to display a short stratigraphic distribution, but suprajacent assemblages must be studied to determinine their actual range. The first Nodosaria liassica in the present sample set (Fig. 2) were found in this zone, but the species is also known from the Aalenian at Murtinheira (Canales and Henriques, 2008). The $R$. spandeli Zone also records the LOs of some typical Toarcian and Aalenian species, such as Nodosaria pseudoregularis, $N$. pulchra, Pseudonodosaria vulgata, Planularia cordiformis, and Falsopalmula jurensis. However, these may be local LOs as some of these species have been identified elsewhere in younger beds.

In summary, foraminiferal diversity decreases slowly through the $L$. quenstedti Zone, reaching a minimum in its upper part, coinciding with the Aalenian-Bajocian transition. A clear renewal of the assemblages occurs in the $R$. spandeli Zone, where some typical Toarcian and Aalenian species disappear to be replaced by numerous, typical Middle Jurassic taxa.

\section{Foraminiferal Bioevents}

As pointed out above, bioevents identified in the Murtinheira section (Fig. 7) include FOs, LOs, or notice- 

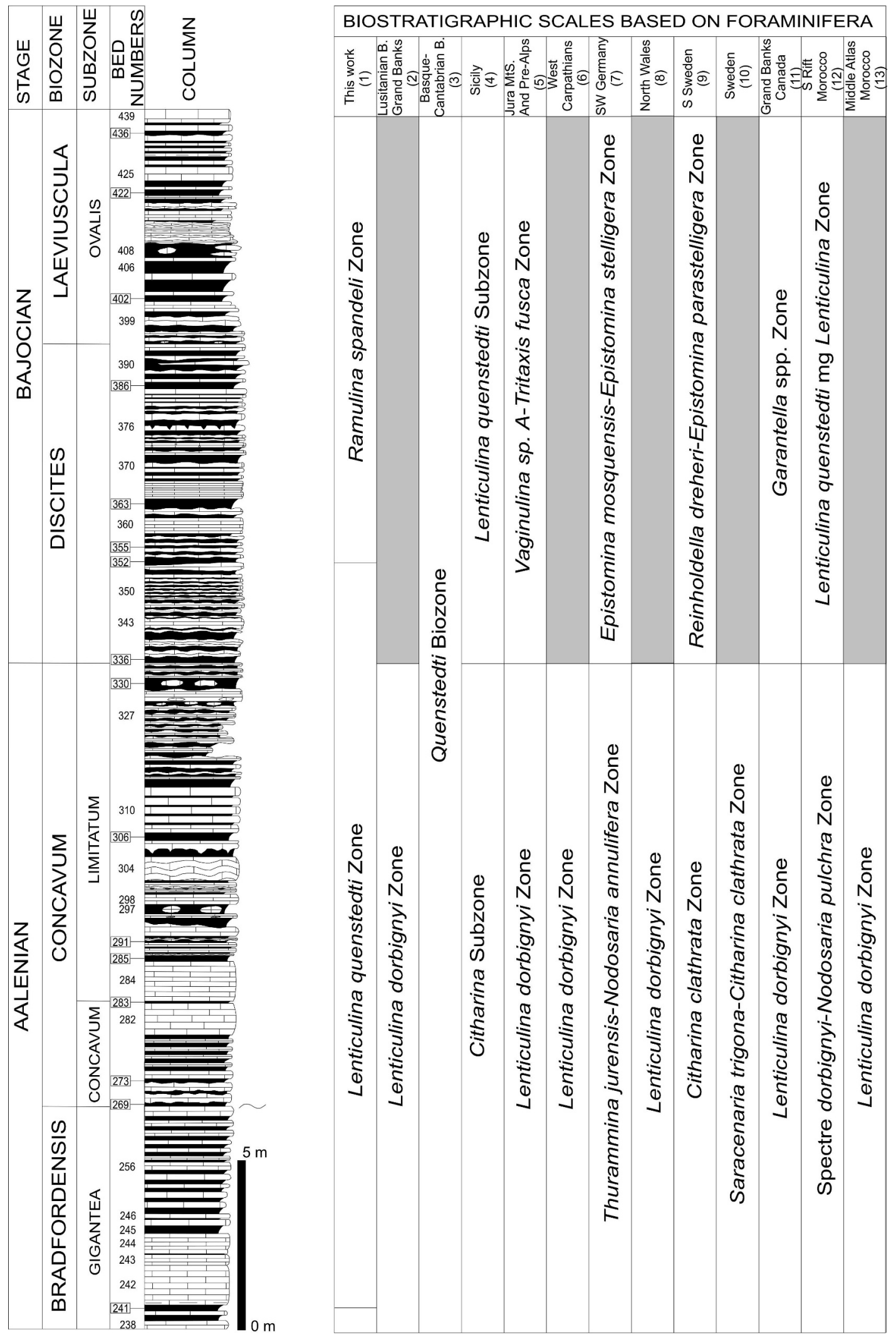

Figure 6. Foraminiferal zones (1) established in this work, compared to foraminiferal zonations in other areas. 2-Lusitanian Basin, Portugal, and Grand Banks, Canada (Exton and Gradstein, 1984); 3-Basque-Cantabrian Basin, N Spain (Canales, 2001); 4 -Sicily, S Italy (Barbieri, 1964); 5-Jura Mountains, France, and Pre-Alps, Switzerland (Septfontaine, 1971; Wernli and Septfontaine, 1971); 6-W Carpathians, Poland (Tyszka, 1999); 7-SW Germany (Frentzen, 1941); 8-N Wales (Copestake and Johnson, 1984); 9-S Sweden (Norling, 1972); 10 — Sweden (Grigelis and Norling, 1999); 11— Grand Banks, Canada (Gradstein, 1977, 1978); 12-S Rift, Morocco (Boutakiout, 1990); 13-Middle Atlas, Morocco (Bejaji and others, 2010). 


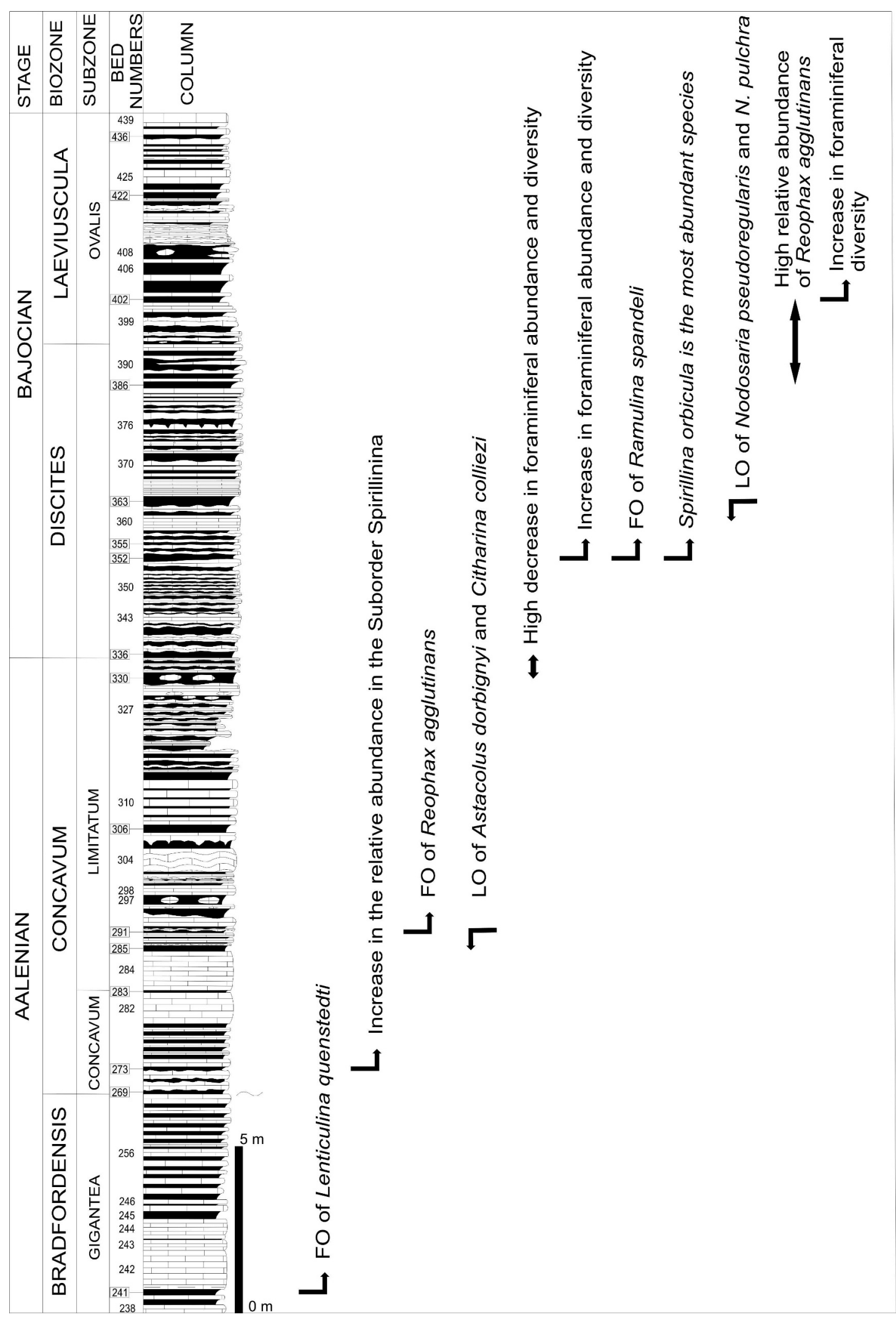

FIGURE 7. Main foraminiferal bioevents recorded in the Bajocian GSSP (Murtinheira section, Lusitanian Basin, W Portugal). 
able changes in the relative abundance of some taxa, as well as variations in the foraminiferal diversity recorded in some assemblages. These bioevents initially have local application, but it may be possible to correlate some of them to coeval rocks in neighboring sections in the Lusitanian Basin or in other basins, hence increasing their biostratigraphic value. The following bioevents occur in the Bajocian GSSP.

The FO of $L$. quenstedti, the index species of the $L$. quenstedti Zone, occurs in level M-241 (upper part of the Gigantea Subzone, Bradfordensis Biozone, middle Aalenian).

The assemblage in sample M-273, corresponding to the lower part of the Concavum Subzone, Concavum Biozone, upper Aalenian, shows an increase in the relative abundance of representatives of the suborder Spirillinina.

Two bioevents occuring in sample M-291 (lower part of the Limitatum Subzone, Concavum Biozone, upper Aalenian) include the LOs of two typical Aalenian species, $A$. dorbignyi and $C$. colliezi, and the $\mathrm{FO}$ of the agglutinated form $R$. agglutinans, which is an important component in some Bajocian assemblages.

Assemblages at the Aalenian-Bajocian transition in samples M-330 and M-336 are composed of a low number of specimens and taxa, reflecting a marked decrease in foraminiferal abundance and diversity.

However, the assemblage in sample M-352 (lower Bajocian, Discites Biozone) documents an important recovery in the number of specimens and taxa, reflecting an increase in foraminiferal abundance and diversity. Additionally, the FO of $R$. spandeli, the index species of the $R$. spandeli Zone, occurs here, and $S$. orbicula from here upwards becomes the most abundant species in all the studied assemblages.

The LOs of Nodosaria pseudoregularis and N. pulchra is recorded in sample M-363 (lower Bajocian, Discites Biozone). Both species are very common in Aalenian foraminiferal assemblages.

Reophax agglutinans notably increases in abundance in samples M-386 (Discites Biozone) and M-402 (Laeviuscula Biozone, Ovalis Subzone). Moreover, a rapid increase in foraminiferal diversity also occurs in sample M-402, where 11 FOs are registered, almost all of them representative of typical Middle Jurassic species.

\section{DISCUSSION}

For the first time, the detailed characterization and description of the foraminiferal assemblages from the Lower Bajocian (Discites Biozone-Laeviuscula Biozone, Ovalis Subzone) at Murtinheira allow recognition of some aspects related to the taxonomic composition of the analyzed assemblages. These findings complement previous studies of upper Toarcian and Aalenian assemblages, thus providing new insight about the biotic components of the Bajocian GSSP.

Canales and Henriques (2008) pointed out that the upper Toarcian (Aalensis Biozone) and Aalenian foraminiferal assemblages from Murtinheira are composed of typical Lower Jurassic species. Furthermore, these authors along with Henriques and others (2010) recorded a strong decrease in the abundance and diversity of foraminiferal assemblages at the Aalenian-Bajocian boundary, a bioevent that can also be recognized in coeval sections from the Basque-Cantabrian Basin in northern Spain (Canales, 2001).

Data reported in this work show that an important renewal in the foraminiferal assemblages occurs in the lower part of the Discites Biozone, where there are numerous FOs of typical Middle Jurassic taxa as well as some LOs of important components of the Aalenian assemblages (Fig. 2). As a consequence, Bajocian foraminiferal assemblages in Murtinheira are generally more abundant and diverse than the Aalenian ones.

Lenticulina is the most abundant genus in the Murtinheira section (Fig. 2), totaling 2126 specimens, representing $53.8 \%$ of the foraminiferal fauna. Equally remarkable is the relative abundance of Spirillina specimens, representing $17.9 \%$ of the total, and those of Astacolus, representing 7.1\%. These data are similar to those obtained in the upper Toarcian-Aalenian foraminiferal assemblages from Murtinheira, described by Canales and Henriques (2008), as well as to the composition of the Aalenian-Bajocian assemblages described by Stam (1985) in Murtinheira and by Carapito and Henriques (1999) in the Serra da Boa Viagem (Lusitanian Basin, Portugal). The dominance of Lenticulina in Lower-Middle Jurassic transitional foraminiferal assemblages is common in other Iberian sections (Herrero and Canales, 1997; Canales and Herrero, 2000; Canales and others, 2000; Canales and others, 2010), and represents a characteristic feature of Middle Jurassic foraminiferal assemblages, as argued by Haynes (1981). Murray (1989) indicated that in Middle Jurassic shallowwater carbonate environments, the foraminiferal assemblages are dominated by species of Lenticulina, Citharina, and Nodosaria. In the Murtinheira section, from the upper Toarcian-lower Bajocian the most abundant genera, besides Lenticulina, are Spirillina and Astacolus. However, rocks corresponding to this stratigraphic interval are interpreted as having been deposited in a deeper-water environment, a distal ramp, which existed in the northern Lusitanian area throughout the Toarcian (Watkinson, 1989; Duarte, 1997; Azerêdo and others, 2003).

Some species differences have been detected between Aalenian and Bajocian assemblages. In the former, $L$. muensteri is the most abundant species, but in almost all Bajocian assemblages (except in M-402) the most abundant species is S. orbicula. Some authors (Haynes, 1981; Tyszka, 1994) indicate that the high number of small Lenticulina specimens is related to the fact that they are opportunistic taxa. However, a detailed analysis of Lenticulina species abundances, identified from several sections of upper Toarcian-lower Aalenian rocks in the Lusitanian Basin and belonging to different paleogeographical settings, reveals that each species shows paleoenvironmental preferences. Thus, $L$. muensteri is more common in distal facies, $L$. helios shows high abundance in the transitional part of the platform, and L. toarcense is more abundant in the proximal marine ramp of the basin (Canales and others, 2010). Some conflicting opinions exist about paleoecological conditions that can be inferred from the presence of Spirillina. Murray (1989) pointed out that this genus indicates normal-marine, relatively shallow, and well-oxygenated conditions. Tyszka 
(2001) indicated that it can occur in a wide variety of paleoenvironments, at nearly all depths between middle neritic-upper bathyal, being more abundant in shallower sites. Bouhamdi and others (2001) showed that the prevalence of Spirillinina over Textulariina indicates assemblages developed in a platform environment. Canales (2001) noticed that the increase in the relative abundance of Spirillina in the assemblages coincides with the transgressive part of sedimentary cycles in the Basque-Cantabrian Basin (Spain). Taking into account all these data and the fact that no apparent changes in paleoenvironmental conditions occur in the Bajocian in Murtinheira, S. orbicula shows its best development in the distal marine ramp of the Lusitanian Basin.

The main difficulty in establishing Jurassic biostratigraphic scales based on benthic foraminifers is that the most common species show very wide stratigraphic ranges (Fig. 2), making them less useful for refined correlations. Species and their stratigraphic ranges identified in Murtinheira allow the definition of a biostratigraphic scale (Fig. 6), including the L. quenstedti and $R$. spandeli zones.

Most Middle Jurassic foraminiferal zonations (Fig. 6) use the Lenticulina dorbignyi Zone for the entire Aalenian stage (Wernli and Septfontaine, 1971; Gradstein, 1977, 1978; Copestake and Johnson, 1984; Exton and Gradstein, 1984; Tyszka, 1999; Bejaji and others, 2010). This biozone has been recognized in several upper Toarcian-lower Aalenian sections from the Lusitanian Basin (Canales and others, 2010). Some other Aalenian stratigraphical scales have been based on typical species of the Boreal Realm (Frentzen, 1941; Barbieri, 1964; Norling, 1972; Grigelis and Norling, 1999) that do not match the Lusitanian Basin because of the irregular record or complete absence of the index species.

On the other hand, L. quenstedti is used in some biostratigraphic proposals (Barbieri, 1964; Boutakiout, 1990) as the index for the Bajocian, Discites Biozone (Fig. 5). In the Basque-Cantabrian Basin (northern Spain), Canales (2001) established the Quenstedti Biozone, whose lower boundary coincides with its FO at the base of the Bradfordensis Subzone, middle Aalenian. Other authors (Frentzen, 1941; Norling, 1972; Gradstein, 1977, 1978) used species of the suborder Robertinina as indices for the lower Bajocian. Robertinins show high diversity during the Middle Jurassic, but their shells are aragonitic and frequently preserved only as unidentifiable internal molds due to diagenetic alteration. Consequently, they are impractical to use for correlation.

The $R$. spandeli Zone is useful for recognizing the lower Bajocian (Discites Biozone) in Murtinheira because the index species is continuously present in the assemblages. Furthermore, $R$. spandeli is relatively abundant and readily identifiable even in broken specimens. For these reasons the species is a good choice for a zonal marker.

Other Aalenian and Bajocian biostratigraphic scales in the Northern Hemisphere have been based on agglutinated foraminifers. However, they do not match the Murtinheira data because they rely on complex (Ekmekci and Altiner, 2008; Yakovleva-O'Neil and others, 2008), or simple (Tyszka and Kaminski, 1995; Basov and others, 2008) agglutinated forms, which are absent or very scarce here.
Henriques and others (2010) first attempted to establish significant bioevents across the Aalenian-Bajocian transition in Murtinheira by comparing changes in the ammonites, calcareous nannofossils, and foraminifers. This study recognizes 11 local foraminiferal bioevents, whose biostratigraphic utility is presently being tested regionally in coeval sections of the Lusitanian Basin (Portugal), the Basque-Cantabrian Basin, and Iberian Range (Spain). One of these bioevents, occurring at the Aalenian-Bajocian transition, is related to the impoverishment of the foraminiferal assemblages. It is also recognized in several sections of the Basque-Cantabrian Basin (Canales, 2001). The causes of this bioevent and its correlation to those of other fossil groups are the scope of several works in progress.

\section{SUMMARY}

This first study of Bajocian foraminifers from Murtinheira (Lusitanian Basin, W Portugal) increases the correlation potential of the Bajocian GSSP. Recovered specimens (Figs. 3-5) are usually well-preserved and show no evidence of taphonomic processes that could change the original assemblage composition. The assemblages are typically Boreal Realm and similar to those found in coeval sections from other Northern Hemisphere basins. Most specimens belong to the suborder Lagenina, but others belong to the Textulariina, Spirillinina, and Robertinina, with minor representation by the Rotaliina. In addition, 24 genera and 54 species were identified. The most abundant genera are Lenticulina, Spirillina, and Astacolus, and the most abundant species are L. muensteri in the Aalenian and $S$. orbicula in the Bajocian.

The foraminiferal assemblages show clear changes throughout the measured section (Fig. 2). The upper Aalenian contains a mixture of typical Lower and Middle Jurassic species that show a slow and progressive replacement of the older by the younger. Foraminifers at the Aalenian-Bajocian transition are strongly impoverished, where only the most abundant assemblage components survive. The assemblages revive in the lower part of the Discites Biozone (lower Bajocian), marked by the LOs of some important upper Toarcian-Aalenian taxa and the FOs of numerous typical Middle Jurassic species, producing more abundant and diverse faunas than in the Aalenian.

A benthic foraminiferal biostratigraphic scale, closely calibrated to the one based on ammonites, is proposed for the Bajocian GSSP (Fig. 6). Two biozones are established on common and easily recognizable, calcareous index species. The first is the Lenticulina quenstedti Zone, ranging from the upper part of the Gigantea Subzone, Bradfordensis Biozone, middle Aalenian to the lower part of the Discites Biozone, lower Bajocian. The second is the Ramulina spandeli Zone, ranging upward from the upper boundary of the underlying $L$. quenstedti Zone. Its upper boundary is undefined.

In addition, 11 bioevents (Fig. 7), based on FOs, LOs, and changes in the relative abundance of taxa or changes in the abundance and diversity in the recorded assemblages, have been recognized in the Murtinheira section. So far most have only local utility, but one of them, namely the impoverished 
foraminiferal assemblages at the Aalenian-Bajocian transition, seems to have, at least, regional importance.

\section{ACKNOWLEDGMENTS}

This study has been supported by the Projects CGL201123947 and CGL2011-25894 (Ministerio de Educación y Ciencia, Spain) and by the Grupo de Investigación UCM 910431 (Complutense University, Madrid, Spain). The laboratory work was supported by the Consórcio Petrobras-Galp-Partex of Portugal. The authors are grateful to András Galácz and to Jarosław Tyszka for the critical review of the manuscript, to the Centro Nacional de Microscopía Electrónica (Complutense University of Madrid, Spain) for the SEM photographs, and to Inês Pena dos Reis for the English revision. Special thanks are due to Paul Brenckle for reviewing the final version of the manuscript.

\section{REFERENCES}

ANDRADE, J. B., 2004, Los Braquiópodos del Tránsito Jurásico InferiorJurásico Medio de la Cuenca Lusitánica (Portugal): Ph.D. Thesis, Universidad Complutense de Madrid, Madrid, $251 \mathrm{p}$.

- 2006, Los braquiópodos del tránsito Jurásico Inferior-Jurásico Medio de la Cuenca Lusitánica (Portugal): Coloquios de Paleontología, v. 56, p. 5-194.

Azerêdo, A. C., Duarte, L. V., Henriques, M. H., and ManupPella, G., 2003, Da Dinâmica Continental no Triásico aos Mares no Jurássico Inferior e Médio: Cadernos de Geologia de Portugal, Instituto Geologico e Mineiro, Lisboa, 43 p.

BArbieri, F., 1964, Micropaleontologia del Lias e Dogger dei pozzo Ragusa 1 (Sicilia): Rivista Italiana di Paleontologia e Stratigrafia, v. 70, p. $709-830$.

BARnARD, T., 1950, Foraminifera from the Upper Lias of Byfield, Northamptonshire: Quarterly Journal of the Geological Society, v. 106, p. $1-36$.

, Cordey, W. G., and Shipp, D. J., 1981, Foraminifera from the Oxford Clay (Callovian-Oxfordian of England): Revista Española de Micropaleontología, v. 13, p. 383-462.

Bartenstein, H., 1948, Entwicklung der Gattung Lenticulina (Lenticulina) Lamarck 1804 mit ihren Unter-Gattungen (For.): Senckenbergiana, v. 29, p. 41-65.

—, and BRAND, E., 1937, Mikro-paläontologische Untersuchungen zur Stratigraphie des nordwest-deutschen Lias und Doggers: Abhandlungen der Senckenbergischen Naturforschenden Gesellschaft, v. 439, p. 1-224.

Basov, V., Nikitenko, B., and Kupriyanova, N., 2008, Lower and Middle Jurassic foraminiferal and ostracod biostratigraphy of the eastern Barents Sea and correlation with northern Siberia: Norwegian Journal of Geology, v. 88, p. 259-266.

Bejaji, Z., Chakiri, S., Reolid, M., and Boutakiout, M., 2010 , Foraminiferal biostratigraphy of the Toarcian deposits (Lower Jurassic) from the Middle Atlas (Morocco). Comparison with western Tethys areas: Journal of the African Earth Sciences, v. 57, p. $154-162$.

Berthelin, G., 1879, Foraminifères du Lias moyen de la Vendée: Revue et Magasin de Zoologie Pure et Apliquée, Paris, Serie 3, v. 7, p. $24-41$.

BieleCKA, W., 1960, Micropalaeontological stratigraphy of the lower Malm in the vicinity of Chrzanów (southern Poland): Instytut Geologiczny Prace, v. 31, p. 1-155.

BoomgaART, L., 1949, Smaller Foraminifera from Bodjonegoro (Java): Smit and Dontje, Sappemeer, 175 p.

Bornemann, J. G., 1854, Über die Lias Formation in der Umgegend von Göttingen und ihre organischen Einschlüsse: A. W. Schade, Berlin, 77 p.

Bouhamd, A., Gaillard, C., and Ruget, C., 2001, Spirillines versus agglutinants: impact du flux organique et intérêt paléoenvironmental (Oxfordien moyen du sud-est de la France): Geobios, v. 34, p. $267-277$.
Boutakiout, M., 1990, Les foraminifères du Jurassique des Rides sudrifaines et des regions voisines (Maroc): Documents des Laboratoires de Géologie de Lyon, v. 112, p. 1-247.

Brilha, J., Andrade, C., Azerêdo, A., Barriga, F. J. A. S., Cachão, M., Couto, H., Cunha, P. P., Crispim, J. A., Dantas, P., Duarte, L. V., Freitas, M. C., Granja, M. H., Henriques, M. H., Henriques, P., Lopes, L., Madeira, J., Matos, J. M. X., Noronha, F., Pais, J., PiçArra, J., Ramalho, M. M., Relvas, J. M. R. S., Ribeiro, A., Santos, A., Santos, V., and Terrinha, P., 2005, Definition of the Portuguese frameworks with international relevance as an input for the European geological heritage characterisation: Episodes, v. 28, p. 177-186.

Brotzen, F., 1948, The Swedish Paleocene and its foraminiferal fauna: Årsbok Sveriges Geologiska Undersökning, v. 42, p. 1-140.

Canales, M. L., 2001, Los foraminíferos del Aaleniense (Jurásico Medio) en la Cuenca Vasco-Cantábrica ( $\mathrm{N}$ de España): Revista Española de Micropaleontología, v. 33, p. 253-438.

_, and Henriques, M. H., 2007, Análisis cuantitativo de los foraminíferos del Aaleniense (Jurásico Medio) de la sección de Murtinheira (Cabo Mondego, W de Portugal). Consideraciones paleoecológicas, in Carvalho, I. S., and others (eds.), Paleontologia: Cenários de Vida: Editora Interciência, Brasil, v. 2, p. 383-393.

, and,- 2008 , Foraminifera from the Aalenian and the Bajocian GSSP (Middle Jurassic) of Murtinheira section (Cabo Mondego, west Portugal): biostratigraphy and paleoenvironmental implications: Marine Micropaleontology, v. 67, p. 155-179. -, and Herrero, C., 2000, Asociaciones de foraminíferos del Toarciense superior y Aaleniense en la sección de Moyuela (Zaragoza, España): Revista Española de Micropaleontología, v. 32, p. 301-317.

- Henriques, M. H., and Ureta, S., 2000, Análisis de las asociaciones de foraminíferos del Aaleniense en los márgenes oriental y noroccidental de la Placa Ibérica: implicaciones biogeográficas y bioestratigráficas: Actas do I Congresso Ibérico de Paleontología/XVI, Jornadas de la Socociedad Española de Paleontología, Évora, Portugal, p. 8, 9.

, - Figueiredo, V. L., and Guterres, H. C., 2010 Foraminifera from the Lower-Middle Jurassic of the Lusitanian Basin (Portugal) - biostratigraphic and palaeoecological significance, in Pena dos Reis, R., and Pimentel, N. (eds.), Rediscovering the Atlantic: New Ideas for an Old Sea: II Central and North Atlantic Conjugate Margins Conference, Lisbon, 2010, p. 42-46.

Carapito, M. C., and Henriques, M. H., 1999, Foraminiferal biostratigraphy and paleoecology of the Aalenian-Bajocian boundary at the Cabo Mondego area: Proceedings of the European Palaeontological Association Workshop, Lisbon, p. 35-38.

Chapman, F., Parr, W. J., and Collins, A. C., 1934, Tertiary foraminifera of Victoria, Australia - the Balcombian deposits of Port Phillip, part III: Journal of the Linnaean Society of London, Zoology, v. 38, p. 553-577.

Coleman, B., 1981, The Bajocian to Callovian, in Jenkins, D. G., and Murray, J. W. (eds.), Stratigraphical Atlas of Fossil Foraminifera: British Micropaleontological Society Series, Ellis Horwood Limited, Chichester, p. 105-124.

Copestake, P., and Johnson, B., 1984, Lower Jurassic (HettangianToarcian) Foraminifera from the Mochras Borehole, North Wales (UK) and their application to a worldwide biozonation: Benthos'83, Second International Symposium on Benthic Foraminifera, Pau, April 1983, p. 183, 184.

, and - 1989, The Hettangian to Toarcian, in Jenkins, D. G., and Murray, J. W. (eds.), Stratigraphical Atlas of Fossil Foraminifera: British Micropaleontological Society Series, 2nd edition, Ellis Horwood Limited, Chichester, p. 129-188.

Cushman, J. A., 1910, A monograph of the foraminifera of the North Pacific Ocean. Part 2. Textulariidae: Bulletin of the U.S. National Museum, v. 42, p. 227-230.

, 1927, An outline of a re-classification of the foraminifera: Contributions from the Cushman Laboratory for Foraminiferal Research, v. 3, p. 1-105.

_ 1933, Foraminifera, their classification and economic use: Cushman Laboratory for Foraminiferal Research, Special Publications, v. 4, p. 1-349. 
- and OzAwA, Y., 1930, A monograph of the foraminiferal family Polymorphinidae, Recent and fossil: Proceedings of the U.S. National Museum, v. 77, p. 1-195.

DE Blainville, H. M. D., 1824, Dictionnaire des Sciences Naturelles, mollus.-morf.: F. G. Levrault, Paris, v. 32, p. 1-567.

, 1827, Manuel de Malacologie et de Conchyliologie (1825): F. G. Levrault, Paris, 647 p.

DE MontFort, P. D., 1808, Conchyliologie systématique et classification méthodique des coquilles: F. Schoell, Paris, v. 1, p. 1-409.

D'Orbigny, A., 1826, Tableau méthodique de la classe des Céphalopódes: Annales des Sciences Naturelles, v. 7, p. 245-314.

, 1839, Foraminifères, in de la Sagra, R., Histoire Physique, Politique et Naturelle de l'Île de Cuba: Arthus Bertrand, Paris, 224 p.

, 1846, Foraminifères Fossiles du Bassin Tertiaire de Vienne (Autriche): Gide et Compagnie, Paris, 312 p.

,- 1850 , Prodrome de paléontologie stratigraphique universelle des animaux mollusques et rayonnés: V. Masson, Paris, v. 2, p. $1-427$.

Defrance, J. L. M., 1824, Dictionnaire des Sciences Naturelles, nil.ojo.: F. G. Levrault, Strasbourg, v. 32, p. 1-567.

Delage, Y., and Hérouard, E., 1896, Traité de Zoologie Concrète, Tome 1, La Cellule et des Protozoaires: Schleicher Frères, Paris, $584 \mathrm{p}$.

Delance, J. H., and Ruget, C., 1989, Foraminifères du Dogger nivernais: Revue de Micropaléontologie, v. 332, p. 195-214.

DiENI, I., 1985, Lenticulina exgaleata, new name for Cristellaria galeata Terquem, 1870, non Reuss, 1851: Bolletino della Società Paleontologica Italiana, v. 23, p. 343.

DuArte, L. V., 1997, Facies analysis and sequential evolution of the Toarcian-lower Aalenian series in the Lusitanian Basin (Portugal): Comunicações do Instituto Geológico e Mineiro, v. 84, p. A60-A63.

EhrenberG, C. G., 1838, Über dem blossen Auge unsichtbare Kalkthierchen und Kieselthierchen als Hauptbestandtheile der Kreidegebirge: Bericht über die zu Bekanntmachung geeigneten Verhandlungen der Königlichen Preussischen Akademie der Wissenschaften zu Berlin, v. 1838, p. 192-200.

_ 1843 , Verbreitung und Einfluss des Mikroskopischen Lebens in Süd- und Nord-Amerika: Physikalische Abhandlungen der Königlichen Akademie der Wissenschaften zu Berlin, 1841, v. 1, p. 291-446.

Eichwald, C. E., 1830, Zoologia Specialis pars Altera: J. Zawadzki, Vilnius, $323 \mathrm{p}$.

Ekmekci, E., and Altiner, D., 2008, Timidonella? primitiva n. sp. (Foraminiferida) from the Middle Jurassic of the eastern Taurides (southern Turkey): remarks on evolutionary steps of hauraniids: Turkish Journal of Earth Sciences, v. 17, p. 73-84.

El Khanchoufi, A., 1988, Les Alternances Mano-Calcaires du Jurassique Inférieur et Moyen de Provence: MicropaléontologieSedimentologie-Paléoécologie: Ph.D. Thesis (3ème Cycle), Université de Provence, Marseille, 225 p.

Ellis, B. F., and Messina, A., 1940-1990, Catalogue of Foraminifera: Museum of Natural History, New York.

Exton, J., and Gradstein, F. M., 1984, Early Jurassic stratigraphy and micropaleontology of the Grand Banks and Portugal, in Westermann, G. E. G. (ed.), Jurassic-Cretaceous Biochronology and Paleogeography of North America: Geological Association of Canada, Special Paper, v. 27, p. 13-30.

Fernández-López, S., Henriques, H., Mouterde, R., Rocha, R., and SADKI, D., 1988a, Le Bajocien inférieur du Cap Mondego (Portugal). Essai de biozonation: Second International Symposium on Jurassic Stratigraphy, Lisbon, v. 1, p. 301-313.

_, Mouterde, R., and Rocha, R. B., 1988b, Les Zurcheria s.1. (Ammonitina, Erycitidae) du Bajocien inférieur du Cap Mondego (Portugal): Second International Symposium on Jurassic Stratigraphy, Lisbon, v. 1, p. 283-300.

- Henriques, H., and Mangold, C., 2006, Ammonite succession at the Bajocian/Bathonian boundary in the Cabo Mondego region (Portugal): Lethaia, v. 39, p. 253-264.

-,$\ldots$, and Pavia, G., 2007, New early Bathonian Bigotitinae and Zigzagiceratinae (Ammonoidea, Middle Jurassic): Rivista Italiana di Paleontologia e Stratigrafia, v. 113, p. 383-399.

- Pavia, G., Erba, E., Guiomar, M., Henriques, M. H., Lanza, R., Mangold, C., Olivero, D., and Tiraboschi, D.,
2009, Formal proposal for the Bathonian GSSP (Middle Jurassic) in the Ravin du Bès (Bas-Auran, SE France): Swiss Journal of Geoscience, v. 102, p. 271-295.

Figueiredo, V., 2009, Foraminíferos da Passagem Jurássico InferiorMédio do Sector Central da Bacia Lusitânica: O Perfil de Zambujal de Alcaria: Ms.C. Thesis, Universidade de Coimbra, Coimbra, $88 \mathrm{p}$.

Franke, A., 1936, Die Foraminiferen des deutschen Lias: Abhandlungen der Preussischen Geologischen Landesanstalt, Neue Folge, v. 169 , p. 6-138.

Frentzen, K., 1941, Die Foraminiferenfaunen des Lias, Doggers und unteren Malms der Umgegend von Blumberg (Oberes Wutachgebiet): Beiträge zur naturkundlichen Forschung im Oberrheingebiet, v. 6, p. 125-402.

GradsteIn, F. M., 1977, Biostratigraphy and biogeography of Jurassic Grand Banks foraminifera, in Schafer, G. H. T., and Bernard, R. P. (eds.), First International Symposium on Benthonic Foraminifera of Continental Margins. Part B. Paleoecology and Biostratigraphy: Maritime Sediments Special Publication, v. 1, p. $567-583$.

, 1978, Jurassic Grand Banks foraminifera: Journal of Foraminiferal Research, v. 8, p. 97-109.

Grigelis, A., and Norling, E., 1999, Jurassic geology and foraminiferal faunas in the NW part of the East European Platform: Research Papers, Sveriges Geologiska Undersökning, Series Ca, v. 89, p. 1-101.

GüMBEL, C. C., 1862, Die Streitberger Schwammlager und ihre Foraminiferen-Einschlüsse: Jahreshefte des Vereins für Vaterländische Naturkunde in Württemberg, v. 18, p. 192-238.

Haeckel, E., 1894, Systematische Phylogenie. Entwurf eines Natürlichen Systems der Organismen auf Grund ihrer Stammesgeschichte. Theil 1. Systematische Phylogenie der Protisten und Pflanzen: Georg Reimer, Berlin, 400 p.

Haynes, J. R., 1981, Foraminifera: Macmillan Publishers Limited, London, $433 \mathrm{p}$.

Henriques, M. H., 1992, Bioestratigrafia e Paleontologia (Ammonoidea) do Aaleniano em Portugal (Sector Setentrional da Bacia Lusitaniana): Ph.D. Thesis, Universidade de Coimbra, Coimbra, $301 \mathrm{p}$.

— 1995 , Les faunes d'ammonites de l'Aalénien Portugais: composition et implications paleobiogéographiques: Geobios, Memoire Special, v. 18, p. 229-235.

,- 2004 , Jurassic heritage of Portugal—state of the art and open problems: Rivista Italiana di Paleontologia e Stratigrafia, v. 110, p. 389-392.

— 2008 , Cabo Mondego, Monumento Natural: Geonovas, v. 21, p. 3,4 .

- , and Mouterde, R., 2000, Importance des graphoceratidés dans les associations enrégistrées au G.S.S.P. du Bajocien (Cabo Mondego, Portugal): Strata, série 1, v. 10, p. 23-27.

+ , and Ramalho, M. M., 2005, Jurassic heritage of Cabo Mondego (Central Portugal), in Henriques, M. H., and others (eds.), Jurassic Heritage and Geoconservation in Portugal: Selected Sites: IV International Symposium ProGEO on the Conservation of the Geological Heritage, Field Trip Guide Book, Geosciences Centre, University of Coimbra, p. 37-43.

- SADKI, D., and Mouterde, R., 1988, Graphoceratidés (Ammonitina) de la base du Bajocien portugais: Second International Symposium on Jurassic Stratigraphy, Lisbon, v. 1, p. $243-254$.

- Gardin, S., Gomes, C. R., Soares, A. F., Rocha, R. B., Marques, J. F., LApA, M. R., and Montenegro, J. D., 1994, The Aalenian-Bajocian boundary at Cabo Mondego (Portugal): Miscellanea, Servizio Geologico Nazionale, v. 5, p. 63-67.

- Linares, A., Sandoval, J., and Ureta, M. S., 1996, The Aalenian in the Iberia (Betic, Lusitanian and Iberian Basins), in Riccardi, A. C. (ed.), Advances in Jurassic Research: GeoResearch Forum, v. 1, 2, p. 139-150.

— Locais com interesse geológico da orla costeira portuguesa entre o Cabo Mondego e a Nazaré: Comunicações do Instituto Geológico e Mineiro, v. 84, p. G6-G9.

- Canales, M. L., and Magno, C., 2008, Paragem 2A-Fácies Distais de Rampa Carbonatada (Sag do 1 Rifte): Jurássico Médio, 
in Pena dos Reis, R., and others (eds.), Roteiro: III Curso de Campo na Bacia Lusitânica (Portugal), Coimbra, p. 33-42.

-, , Neto, K., and Antunes, R. L., 2010, Significant bioevents across the Bajocian GSSP (Cape Mondego, Portugal), in Pena dos Reis, R., and Pimentel, N. (eds.), II Central and North Atlantic Conjugate Margins Conference, Lisbon 2010, Field-Trip Guidebook, Lusitanian Basin (Portugal), p. 33-42.

Herrero, C., and Canales, M. L., 1997, Diversidad en los foraminíferos del tránsito Toarciense/Aaleniense en la sección de Fuentelsaz (Cordillera Ibérica): Revista Española de Paleontología, v. 12 , p. 233-242.

, and - 2002, Taphonomic processes in selected Lower and Middle Jurassic foraminifera from the Iberian Range and Basque-Cantabrian Basin (Spain): Journal of Foraminiferal Research, v. 32, p. 22-42.

Hohenegger, J., and Piller, W., 1975, Wandstrukturen und Grossgliederung der Foraminiferen: Sitzungsberichten der Österreichisch Akademie der Wissenschaften, Mathematisch-naturwissenschaftliche Klasse, Abteilung I, v. 184, p. 67-96.

ICNB, 2009, Monumentos Naturais: Instituto da Conservação da Natureza e da Biodiversidade, http://portal.icnb.pt/ICNPortal/ vPT2007/O+ICNB/Áreas+Protegidas/Monumentos+Naturais/ (Acesso: 3/01/2010).

Jones, T. R., and PARKER, W. K., 1860, On some fossil Foraminifera from Chellastone near Derby: Quarterly Journal of the Geological Society of London, v. 16, p. 452-458.

Kalantari, A., 1969, Foraminifera from the Middle JurassicCretaceous successions of Koppet-Dagh region (NE Iran): National Iranian Oil Company, Geological Laboratory, v. 3, p. 1-298.

KaPtAREnKo-Chernousova, O. K., 1956, K voprosi o vidoobrazovanii i sistematike yurskikh epistominid (La genèse des espèces et la systématique des Epistominidés jurassiques): Voprosy Micropaleontologii, v. 1, p. 49-61. (in Russian, translated into French by S. and J. Sigal)

_ 1961, Lentculinini Jurs'kikh vidladiv Dniprovs'ko-Donets'koi Zapadini ta Okrain Donbasu (Lenticulininae of Jurassic deposits of the Dnepr-Donets basin and Donbass environs): Trudy Instituta Geologicheskikh Nauk Akademiya Ukraynskoy RSR, Kiev, Seriya Stratigrafii i Paleontologii, v. 36, p. 1-102. (in Russian)

Kasimova, G. K., Poroshina, L. A., and Geodakchan, A. A., 1980, Novoe semeystvo Placentulinidae i osobennosti ego razvitiya $\mathrm{V}$ Yure i Melu (The new family Placentulinidae and peculiarities of its development during the Jurassic and Cretaceous): Voprosy Mikropaleontologii, v. 23, p. 121-126. (in Russian with English abstract)

Lalicker, C. G., 1950, Foraminifera of the Ellis Group, Jurassic, at the type locality: Kansas University, Paleontological Contributions, Protozoa, v. 2, p. 3-20.

LAmarck, J. B., 1804, Suite des mémoires sur les fóssiles des environs de Paris: Annales Muséum National d'Histoire Naturelle, v. 5, p. $179-188$

_ 1812 , Extrait du Cours de Zoologie du Muséum d'Histoire Naturelle sur les Animaux Invertèbres: D'Hautel, Paris, 127 p.

LinNÉ, C., 1758, Systema Naturae: L. Salvii, Stockholm, 10th edition, v. 1 , p. $1-824$

Loeblich, A. R., JR., and TAPPAN, H., 1984, Suprageneric classification of the Foraminiferida (Protozoa): Micropaleontology, v. 30, p. $1-70$

$\longrightarrow$, and $—$ 1986, Some new and redefined genera and families of Textulariina, Fusulinina, Involutinina, and Miliolina (Foraminiferida): Journal of Foraminiferal Research, v. 16, p. 334-346. , and - 1987, Foraminiferal Genera and Their Classification: Van Nostrand Reinhold Company, New York, 2 v., 1182 p.

López-Otálvaro, G. E., Suchéras-Marx, B., Giraud, F., MatTIOLI, E., and LECUYER, C., 2012, Discorhabdus as a key coccolith genus for paleoenvironmental reconstructions (Middle Jurassic, Lusitanian Basin): biometry and taxonomic status: Marine Micropaleontology, v. 94/95, p. 45-57.

Magno, C., Henriques, M. H., and Canales, M. L., 2008, Foraminíferos do Aaleniano (Jurássico Médio) da Ibéria: bacias Lusitânica (Portugal), Basco-Cantábrica (Espanha) e Cordilheira Ibérica (Espanha): Memórias é Notícias, v. 3 (Nova Série), p. 115-122.
Montagu, G., 1808, Testacea Britannica, Supplement: S. Woodmer, Exeter, 183 p.

Morris, P. H., and Coleman, B., 1989, The Aalenian to Callovian (Middle Jurassic), in Jenkins, D. G., and Murray, J. W. (eds.), Stratigraphical Atlas of Fossil Foraminifera: British Micropaleontological Society Series, 2nd edition, Ellis Horwood Limited, Chichester, p. 189-236.

Mouterde, R., Ruget, C., and Caloo, B., 1972, Les limites d'étages. Examen du problème de la limite Aalénien-Bajocien: Mémoires du Bureau de Recherches Géologiques et Minières, v. 77, p. 59-68.

Murray, J. W., 1989, An outline of faunal changes through the Phanerozoic, in Jenkins, D. G., and Murray, J. W. (eds.), Stratigraphical Atlas of Fossil Foraminifera: British Micropaleontological Society Series, 2nd edition, Ellis Horwood Limited, Chichester, p. $570-573$.

Neugeboren, J. L., 1856, Die Foraminiferen aus der Ordnung der Stichostegier von Öber-Lapugy in Siebenbürgen: Kaiserliche Akademie der Wissenchaften, Mathematisch-Naturwissenchaftlige Klasse, Denkschriften, v. 12, p. 65-108.

NorLING, E., 1968, On Liassic nodosariid foraminifera and their wall structures: Årsbok Sveriges Geologiska Undersökning 61(8), Series C, v. 623, p. 1-75.

_ 1972, Jurassic stratigraphy and Foraminifera of western Scania, southern Sweden: Sveriges Geologiska Undersökning, Series Ca, v. 47, p. 1-120.

Oumalch, F., 1979, Étude Stratigraphique et Micropaléontologique du Jurassique du Jbel Dhar en Nsour (Rides Sud-Rrifaines, Maroc): Ph.D. Thesis (3ème Cycle), Université Pierre et Marie Curie, Paris, 190 p.

PaAlzow, R., 1917, Beiträge zur Kenntnis der Foraminiferen Fauna der Schwammergen des unteren Weissen Jura Süddeutschland: Abhandlungen der Naturhistorischen Gesellschaft zu Nürnberg, v. 19 , p. $203-248$.

_ 1932, Die Foraminiferen aus den Transversarius-Schichten und Impressa-Tonen der nordöstlichen Schwäbischen Alb: Jahreshefte des Vereins für vaterländische Naturkunde in Württemberg, v. 88, p. $81-142$.

PARKER, W. K., and JONES, T. R., 1859, On the nomenclature of the foraminifera. II. On the species enumerated by Walker and Montagu: Annals and Magazine of Natural History, ser. 3, v. 4, p. 333-351.

Pavia, J., and Enay, R., 1997, Definition of the Aalenian-Bajocian stage boundary: Episodes, v. 20, p. 16-22.

Pena dos Reis, R., and Henriques, M. H., 2009, Approaching an integrated qualification and evaluation system of the geological heritage: Geoheritage, v. 1, p. 1-10.

Perilli, N., Henriques, M. H., and Giannetti, M., 2002a, Aalenian calcareous nannofossil changes and Lotharingius/Watznaueria turnover: evidence from the Lusitanian Basin (Portugal): Journal of Nannoplankton Research, v. 24, p. 145.

- - , and Ureta, M. S., 2002b, Aalenian calcareous nannofossils biohorizons of some sections from Lusitanian Basin and Basque-Cantabrian Area: Publicaciones del Seminario de Paleontología de Zaragoza, v. 5, p. 162-166.

QuenstedT, F. A., 1856, Der Jura: Laupp, Tübingen, v. 2, p. 209-368. , 1857, Der Jura: Laupp, Tübingen, v. 4, p. 577-842.

ReIss, Z., 1963, Reclassification of perforate foraminifera: Bulletin of the Geological Survey of Israel, v. 35, p. 1-111.

Reuss, A. E., 1846, Die Versteinerungen der böhmischen Kreideformation, pt. 2: E. Schweizerbart'sche Verlagsbuchhandlung und Druckerei, Stuttgart, 148 p.

, 1850, Neues Foraminiferen aus den Schichten des österreichischen Tertiärbeckens: Denkschriften der Kaiserlichen Akademie der Wissenschaften, Mathematisch-Naturwissenschaftliche Classe, v. 1, p. 365-390.

__ 1860 , Über die Frondicularideen, eine Familie der polymeren Foraminiferen: Sitzungsberichte der Königlichen Böhmischen Gessellschaft der Wissenschaften in Prag, Mathematisch-Naturwissenschaftliche Classe, v. 1860, p. 77-92.

, 1862, Entwurf einer systematischen Zusammenstellung der Foraminiferen: Sitzungsberichte der Kaiserlichen Akademie der Wissenschaften in Wien, Mathematisch-Naturwissenschaftliche Classe, v. 44, p. $355-396$.

, 1863, Die Foraminiferen des norddeutschen Hils and Gault: Sitzungsberichte der Kaiserlichen Akademie der Wissenschaften in 
Wien, Mathematisch-Naturwissenschaftliche Classe (1862), v. 46, p. $5-100$.

$\longrightarrow$, and FrITSCH, A., 1861, Verzeichniss von 100 Gypsmodellen von Foraminiferen, welche unter der Leitung des Prof. Dr. A. Reuss und Dr. Anton Fritsch gearbeitet wurden: Karl Seyfried, Prague.

Rhumbler, L., 1904, Systematische Zusammenstellung der recenten Reticulosa: Archiv für Protistenkunde, v. 3, p. 181-294.

Rocha, R., Henriques, M. H. P., Soares, A. F., Mouterde, R., Caloo, B., Ruget, C., and Fernández-López, S., 1990, The Cabo Mondego section as a possible Bajocian boundary stratotype: Memoria Descrittive della Carta Geologica d'Italia, v. 60, p. 49-60.

Roemer, F. A., 1839, Die Versteinerungen des norddeutschen Oolithen-Gebirges: Hannover, 59 p.

Ruget, C., 1973, Inventaire des microfaunes du Bathonien moyen de l'Algarve (Portugal): Revista da Faculdade de Ciências de Lisboa, $2^{\text {a }}$ Serie, C, v. 17, p. 515-542.

- Cubaynes, R., Nicollin, J. P., and Roquet, A. M., 1989, Une méthode de traitement (prélèvement, lavage, tri) pour l'analyse paléoécologique appliquée aux nodosariidés du Toarcien des coupes de Penne et Caylus (Quercy, France): Revue de Micropaléontologie, v. 32, p. 45-52.

RzeHAK, A., 1885, Bemerkungen über einige Foraminiferen der Oligocän Formation: Verhandlungen des Naturforschenden Vereins in Brünn (1884), v. 23, p. 123-129.

Saidova, KH. M., 1981, Osovremennom Sostoyanii Sistemy Nadvidovykh Kaynozoyskikh Bentosnykh Foraminifer (On an Up-toDate System of Supraspecific Taxonomy of Cenozoic Benthonic Foraminifera): Institut Okeanologii P. P. Shirshova, Akademiya Nauk SSSR, Moscow, 73 p. (in Russian)

Schwager, C., 1865, Beiträge zur Kenntnis der mikroskopischen Fauna jurassischer schichten: Jahreshefte des Vereins für vaterländische Naturkunde in Württemberg, v. 21, p. 1-142.

__ 1877, Quadro del proposto sistema de classificazione dei foraminiferi con guscio: Bolletino R. Comitato Geologico d'Italia, v. 8, p. 18-27.

Seibold, E., and Seibold, I., 1960, Foraminiferen der Bank- und Schwamm-Fazies im unteren Malm Süddeutschlands: Neues Jahrbuch für Geologie und Paläontologie, Abhandlungen, v. 109, p. 309-438.

Seiglie, G. A., and Bermúdez, P. J., 1965, Observaciones sobre foraminíferos rotaliformes con cámaras suplementarias o estructuras semejantes (1): Boletín del Instituto Oceanográfico, Universidad de Oriente, Cumana, v. 4, p. 155-171.

SePtFontaine, M., 1971, Étude Microplaléontologique et Stratigraphique du Lias Supérieur et du Dogger des Preálpes Medianes Romandes (Suisse): Ph.D. Thesis, Université de Gèneve, Gèneve, 33 p.

Séronie-Vivien, R. M., Magne, J., and Malmoustier, J., 1961, Le Lias des bordures septentrionale et orientale du bassin d'Aquitanie: Mémoires du Bureau de Recherches Géologiques et Minières, v. 4, p. $757-791$

SilvestrI, A., 1903, Linguloglanduline e Lingulonodosarie: Atti della Pontificia Academia Romana dei Nuovi Lincei, Roma, v. 56, p. 45-50.

StAM, B., 1985, Quantitative analysis of Middle and Late Jurassic foraminifera from Portugal and its implications for the Grand Banks of Newfoundland: Utrecht Micropaleontological Bulletin, v. 34 , p. $1-168$.

Strickland, H. E., 1846, On two species of microscopic shells found in the Lias: Quarterly Journal of the Geological Society of London, v. 2, p. 30, 31 .

Tappan, H., 1955, Foraminifera from the Artic Slope of Alaska. Part 2, Jurassic Foraminifera: U.S. Geological Survey Professional Paper 236-B, p. 21-90.

Terquem, M. O., 1863, Troisième mémoire sur les foraminifères du Lias des départements de la Moselle, de la Côte d'Or, du Rhône, de la Vienne et du Calvados: Extrait des Mémoires de l'Academie Imperial de Metz, p. 151-228.

— comprenant les polymorphines des départements de la Moselle, de la Côte d'Or et de l'Indre: Mémoire de l'Academie de Metz et de la Société géologique de France, p. 233-308.

-1866 , Sixième mèmoire sur les foraminifères du Lias des départements de l'Indre et de la Moselle: Mémoire de l'Academie de Metz et de la Société géologique de France, p. 459-532.
1868, Première mémoire sur les foraminifères du Système Oolithique. Étude du Fullers-Earth de la Moselle: Bulletin de la Société d'Histoire Naturelle de la Moselle, v. 11, p. 1-138.

$\ldots$ Oolithique, comprenant les genres Frondicularia, Flabellina, Nodosaria, Dentalina, etc., de la zone à Ammonites parkinsoni de Fontoy (Moselle): Mémoires de l'Academie Imperiale de Metz, série 2, v. 18, p. 195-278.

—, $1870 \mathrm{~b}$, Deuxième mémoire sur les foraminifères du Système Oolithique. Monographie des cristellaires de la zone à Ammonites parkinsoni de Fontoy (Moselle): Mémoires de l'Academie Imperiale de Metz, v. 50, p. 403-486.

— 1874 , Quatrième mémoire sur les foraminifères du Système Oolithique, comprenant les genres Polymorphina, Guttulina, Spiroloculina, Triloculina, Quinqueloculina de la Zone à Ammonites parkinsoni de Fontoy (Moselle): Mémoires de l'Academie Imperiale de Metz, série 2, v. 18, p. 279-338.

$\longrightarrow, 1886$, Les Foraminifères et les ostracodes de Fuller's Earth des environs de Varsovie: Mémoires de la Société géologique de France, série 3, v. 4, p. 1-112.

$\longrightarrow$, and Berthelin, G., 1875, Étude microscopique des marnes du Lias moyen d'Essay-lès-Nancy, zone inférieure de l'assise à Ammonites margaritatus: Mémoires de la Société géologique de France, 2è série, v. 10, p. 1-126.

TYszKA, J., 1994, Response of Middle Jurassic benthic foraminiferal morphogroups to dysoxic/anoxic conditions in the Pieniny Klippen Belt, Polish Carpathians: Palaeogeography, Palaeoclimatology, Palaeoecology, v. 110, p. 55-81.

- 1999, Foraminiferal biozonation of the Early and Middle Jurassic in the Pieniny Klippen Belt (Carpathians): Bulletin of the Polish Academy of Sciences, Earth Sciences, v. 47, p. 27-46.

_ 2001, Microfossil assemblages as bathymetric indicators of the Toarcian/Aalenian "Fleckenmergel" facies in the Carpathian Pieniny Klippen Belt: Geologica Carpathica, v. 52, p. 147-158.

- , and KAMINSKI, M. A., 1995, Factors controlling the distribution of agglutinated foraminifera in Aalenian-Bajocian dysoxic facies (Pieniny Klippen Belt, Poland) in Kaminski, M. A., and others (eds.), Agglutinated Foraminifera: The Grzybowski Foundation, Special Publication, v. 3, p. 271-291.

Watkinson, M. P., 1989, Triassic to Middle Jurassic Sequences from the Lusitanian Basin, Portugal, and Their Equivalents in Other North Atlantic Margin Basins: Ph.D. Thesis, The Open University, Milton Keynes, 390 p.

WedEKIND, P. R., 1937, Einführung in die Grundlagen der historischen Geologie. Band II. Mikrobiostratigraphie die Korallen- und Foraminiferen-enzeit: Ferdinand Enke, Stuttgart, p. 109-136.

WernLI, R., 1971, Les foraminifères du Dogger du Jura méridional (France): Archives des Sciences, v. 24, p. 305-364.

- and SePtfontaine, M., 1971, Micropaléontologie comparée du Dogger du Jura méridional (France) et des Préalpes médianes plastiques romandes (Suisse): Eclogae Geologicae Helvetiae, v. 64, p. $437-458$.

WIŚNIOWSKI, T., 1890, Mikrofauna ilów ornatowych okolicy Krakowa; cześć I-Otwornice górnego kelowayu w Grójcu: Pamiętnik Akademii Umiejętności w Krakovie, Wydzial MatematycznoPrzyrodniczy, v. 17, p. 181-242.

Wright, J., 1875, A list of the Cretaceous microzoa of the north of Ireland: Proceedings Belfast Naturalists' Field Club (1873-1880), new series 1 (Appendix 3), p. 73-99.

Yakovleva-O'Neill, S. P., Kaminski, M. A., and Gradstein, F. M., 2008, Jurassic benthic foraminiferal biostratigraphy and palaeoecology at the Shtokman Structure, Barents Sea in Kaminski, M. A., and Filipescu, S. (eds.), Proceedings of the Eighth International Workshop on Agglutinated Foraminifera: The Grzybowski Foundation, Special Publication, v. 16, p. 343-356. 